\title{
UMTRA PROJECT WATER SAMPLING AND ANALYSIS PLAN, Naturita, Colorado
}

September 1995

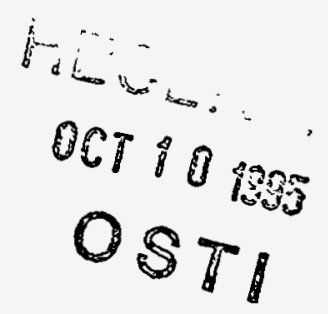

\section{DISCLAIMER}

This report was prepared as an account of work sponsored by an agency of the United States Government. Neither the United States Government nor any agency thereof, nor any of their employees, makes any warranty, express or implied, or assumes any legal liability or responsibility for the accuracy, completeness, or usefulness of any information, apparatus, product, or process disclosed, or represents that its use would not infringe privately owned rights. Reference herein to any specific commercial product, process, or service by trade name, trademark, manufacturer, or otherwise does not necessarily constitute or imply its endorsement, recommendation, or favoring by the United States Government or any agency thereof. The views and opinions of authors expressed herein do not necessarily state or reflect those of the United States Government or any agency thereof.
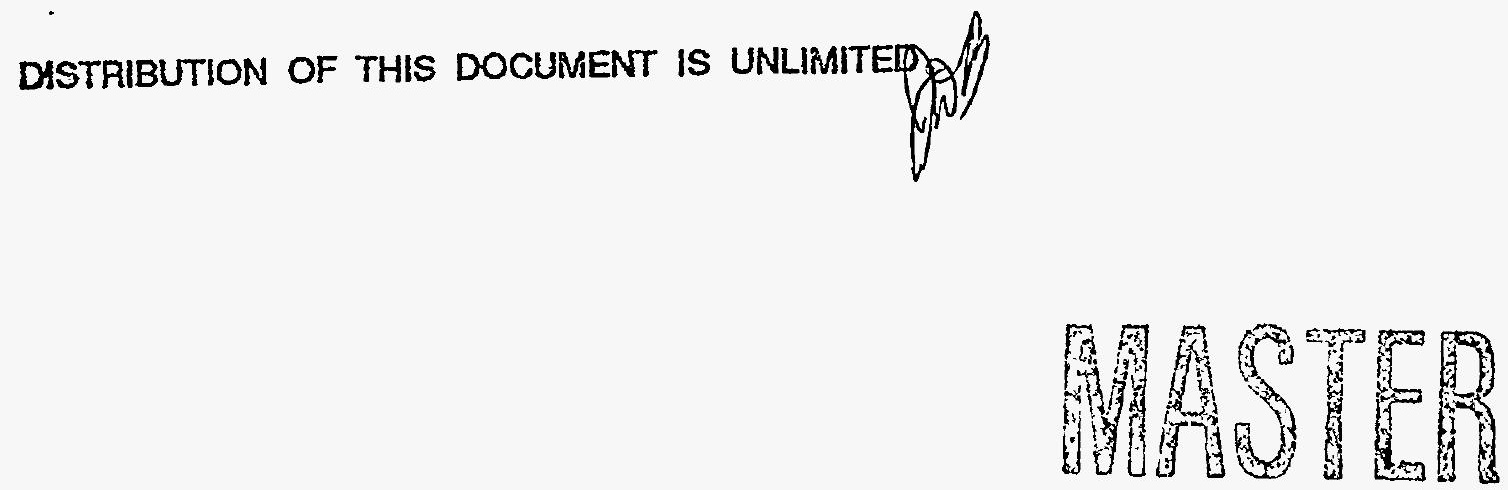
INTENDED FOR PUBLIC RELEASE

This report has been reproduced from the best available copy. Available in paper copy and microfiche.

Number of pages in this report: 64

DOE and DOE contractors can obtain copies of this report from:

Office of Scientific and Technical Information

P.O. Box 62

Oak Ridge, TN 37831

(615) 576-8401

This report is publicly available from:

National Technical Information Service

Department of Commerce

5285 Port Royal Road

Springfield, VA 22161

(703) 487-4650 


\section{DISCLAIMER}

Portions of this document may be illegible in electronic image products. Images are produced from the best available original document. 


\title{
UMTRA PROJECT WATER SAMPLING AND ANALYSIS PLAN, NATURITA, COLORADO
}

September 1995

\author{
Prepared for \\ U.S. Department of Energy \\ Environmental Restoration Division \\ UMTRA Project Team \\ Albuquerque, New Mexico
}

\author{
Prepared by \\ Jacobs Engineering Group Inc. \\ Albuquerque, New Mexico
}




\section{TABLE OF CONTENTS}

Section

Page

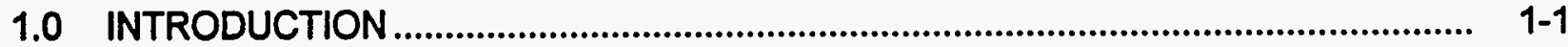

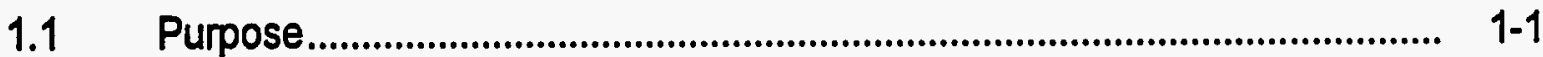

$1.2 \quad$ Site location .............................................................................................. $1-1$

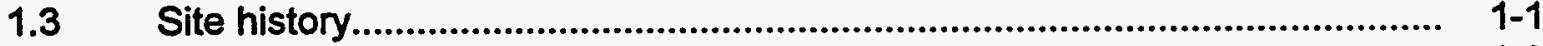

$1.4 \quad$ Site status ........................................................................................... $1-3$

$1.5 \quad$ Sampling plan summary ....................................................................... 1-3

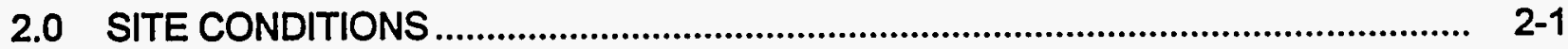

$2.1 \quad$ Site background information................................................................ $2-1$

2.1.1 Surrounding land uses.................................................................... $2-1$

2.1.2 Surrounding water use................................................................ $2-1$

2.1.3 Contaminant sources................................................................. 2-3

$2.2 \quad$ Geology and hydrology ....................................................................... 2-3

2.2.1 Physical setting............................................................................. 2-3

2.2.2 Geology ....................................................................................... $2-4$

2.2.3 Ground water hydrology............................................................... $2-4$

2.2.4 Surface water hydrology ................................................................ 2-10

$2.3 \quad$ Water quality ........................................................................................... 2-10

2.3.1 Background water quality................................................................. 2-10

2.3.2 Point of compliance ..................................................................... 2-11

2.3.3 Contaminant delineation.............................................................. 2-11

2.3.4 Surface water sampling locations ................................................... 2-20

$2.4 \quad$ Site conceptual model .................................................................................... 2-23

3.0 DATA COLLECTION OBJECTIVES .................................................................. $3-1$

3.1 Regulatory requirements ........................................................................ $3-1$

3.2 Compliance monitoring................................................................................. $3-1$

3.3 Site characterization.................................................................................... $3-1$

$3.4 \quad$ Other considerations .................................................................................. $3-1$

4.0 DATA QUALITY REQUIREMENTS .....................................................................

4.1 Analytical methods, holding times, and $\ldots$

4.2 Sample filtration.................................................................................... $\quad 4-1$

4.3 Sample preservation and shipment.............................................................. 4-1

4.4 Chain-of-custody procedures ......................................................................... 4- 4-1

4.5 Sample collection methods and sequence ................................................. 4-6 


\section{TABLE OF CONTENTS (Concluded)}

Section

Page

5.0 SAMPLING PLAN

$5-1$

5.1 Sampling locations

$5-1$

5.2 Analytical parameters

5-1

5.3 Sampling frequency

$5-2$

5.4 Data evaluation methods

$5-2$

5.5

Response to anomalous data.

5-3

6.0 LIST OF CONTRIBUTORS

6-1

7.0 REFERENCES

$7-1$ 


\section{LIST OF FIGURES}

Section

Page

$1.1 \quad$ Location of Naturita, Colorado, site ........................................................... 1-2

1.2 Aerial photograph, Naturita, Colorado, site .................................................. 1-4

1.3 Locations of active and abandoned DOE monitor wells,

Naturita, Colorado, site

$1.4 \quad$ Location of private wells and surface sampling locations, Naturita, Colorado, site ............................................................................. 1-6

2.1 Location of private wells, Naturita, Colorado, site .......................................... 2-2

2.2 Rocks and hydrogeologic units present in the area, Naturita, Colorado, site

2.3 Ground water table elevation and trend of hydrogeologic cross-section A-A', Naturita, Colorado, site.

2.4 Hydrogeological cross-section A-A', Naturita, Colorado, site

2.5 Major element classification of ground water from DOE alluvial and

Salt Wash monitor wells at the Naturita, Colorado, site.

2.6 Chloride isopleth map, Naturita, Colorado, site

2.7 Uranium concentrations in the ground water in the alluvium, Naturita, Colorado, site

2.8 Hydrogeological cross-section A-A' showing the distribution of uranium concentration, Naturita, Colorado, site

\section{LIST OF TABLES}

Section

Page

1.1 Monitor well completion data, Naturita, Colorado, site ....................................... 1-8

1.2 Sampling locations at the Naturita site .......................................................... 1-9

2.1 Comparison of background and on-site ground water quality in the alluvial aquifer and downgradient spring water quality, Naturita, Colorado, site

2.2 Comparison of upstream and downstream water quality data for constituents above background in ground water, San Miguel River, Naturita, Colorado, site.

4.1 Sampling preservation techniques and holding times

4.2 UMTRA Project detection limits and techniques 


\section{LIST OF ACRONYMS AND ABBREVIATIONS}

Acronym

BLM

BLRA

COC

DOE

DQO

EA

EPA

JEG

MCL

RAP

SOP

TAD

TDS

UMTRA

USGS

VCA

WSAP

\section{Definition}

Bureau of Land Management

baseline risk assessment

chain of custody

U.S. Department of Energy

data quality objective

environmental assessment

U.S. Environmental Protection Agency

Jacobs Engineering Group

maximum concentration limit

remedial action plan

standard operating procedures

Technical Approach Document

total dissolved solids

Uranium Mill Tailings Remedial Action

U.S. Geological Survey

Vanadium Corporation of America

water sampling and analysis plan 


\subsection{INTRODUCTION}

\subsection{PURPOSE}

Planned, routine ground water sampling activities for calendar year 1995 to 1997 at the U. S. Department of Energy (DOE) Uranium Mill Tailings Remedial Action (UMTRA) Project site near Naturita, Colorado, are described in this water sampling and analysis plan (WSAP). The following plan identifies and justifies the sampling locations, analytical parameters, detection limits, sampling frequency, and specific rationale for each routine monitoring station at the site.

The regulatory basis for routine ground water monitoring at UMTRA Project sites is derived from the U.S. Environmental Protection Agency (EPA) regulations in 40 CFR Part 192. Sampling procedures are guided by the UMTRA Project standard operating procedures (SOP) (JEG, n.d.), the Technical Approach Document (TAD) (DOE, 1989), and the most effective technical approach for the site.

\subsection{SITE LOCATION}

The Naturita site is in the southwestern portion of Colorado, in Montrose County, about 2 miles (mi) (3 kilometers [km]) northwest of the town of Naturita along Colorado State Highway 141 (Figure 1.1). The site is on the west bank of the San Miguel River.

\subsection{SITE HISTORY}

The Naturita plant was built by the Rare Metals Company in 1930, although operations did not start until 1939, after being purchased and refitted by Vanadium Corporation of America (VCA) for vanadium production (Merritt, 1971). In 1942, the mill was altered again to process uranium as well as vanadium. The first shipments of uranium concentrates began in 1947; the mill was shut down in 1958.

During 1961 to 1963, the VCA operated an upgrader plant making a sand-slime separation at the Naturita site (Merritt, 1971). The slime concentrates were shipped to Durango, Colorado, for further treatment. From 1947 to 1963 , the mill processed 704,000 tons $(639,000$ tonnes) of uranium-vanadium ore (FB\&D, 1981).

During the period 1939 to 1942 , a salt-roast and water-leaching process was used for vanadium recovery. Water for the process was obtained from the San Miguel River (FB\&D, 1981). After 1942, both uranium and vanadium were extracted by salt roasting, followed by carbonate leaching in percolation tanks. Carbonate leach tails were slurried to the western half of the site, north of the mill area (DOE, 1995a). The extractions of uranium and vanadium at this point were usually less than 80 percent effluent. To increase the efficiency of the process, the carbonate-residues 


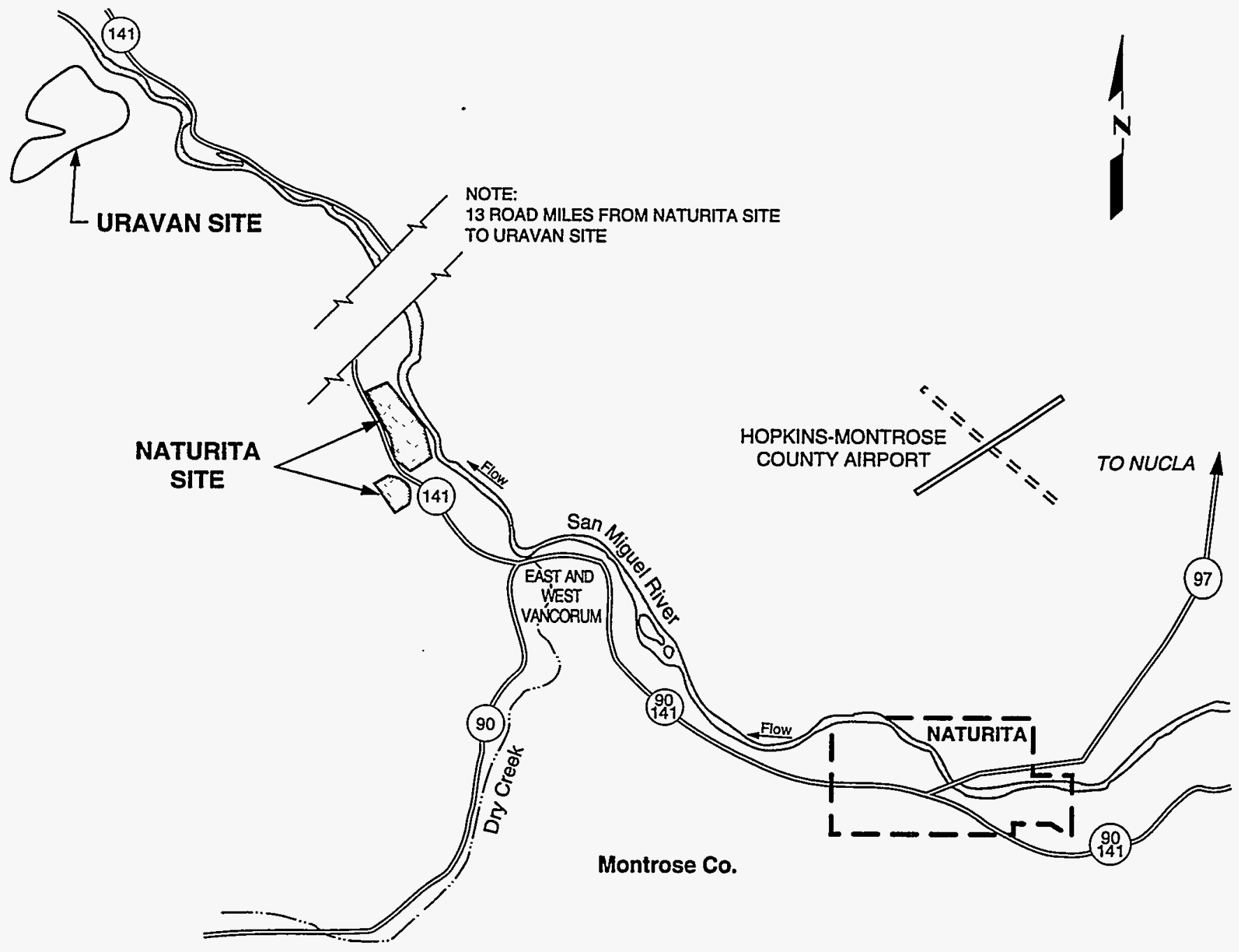

LEGEND

NOT TO SCALE

(90) STATE HIGHWAY

EPHEMERAL STREAM

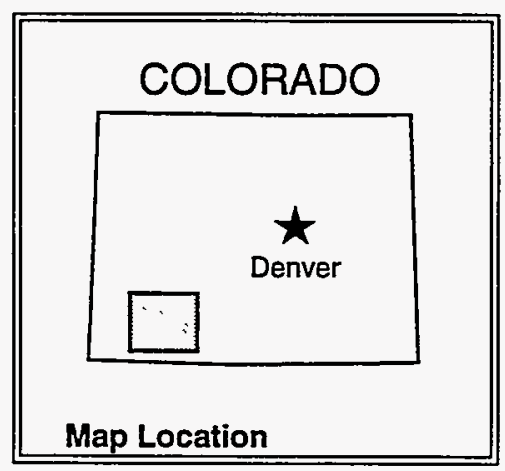

MODIFIED FROM DOE, 1994. 
were processed through a second stage of sulfuric acid percolation leaching. As a result, an additional 15 to 20 percent of the uranium and vanadium were extracted. A small amount of ammonium sulfate was used at this point as a purifying measure (DOE, 1995a). Acid leach tails were deposited to the east of the mill site between the mill yard and the San Miguel River (DOE, 1995a). Figure 1.2 shows the Naturita uranium processing site during its operating period.

The tailings were removed from the site to a heap-leach reprocessing plant located along State Highway 90 , about $3 \mathrm{mi}(5 \mathrm{~km})$ southeast of the intersection of Highways 90 and 141 at Coke Oven during 1977 to 1979. After being reprocessed, the tailings were stabilized at that location with 2 to 10 feet (ft) (.6 to 3 meters [m]) of cover. In the late 1970 s to eariy 1980 s, a portion of the Naturita site was leased to General Electric Company for a uranium ore-buying station (DOE, 1994a).

The remaining contaminated material includes about 117,000 cubic yards $\left(\mathrm{yd}^{3}\right)$ $\left(89,500\right.$ cubic meters $\left.\left[\mathrm{m}^{3}\right]\right)$ of contaminated soil from the former tailings pile area, about $115,000 \mathrm{yd}^{3}\left(87,900 \mathrm{~m}^{3}\right)$ of contaminated soil in the former mill yard, and about $8,000 \mathrm{yd}^{3}\left(6,000 \mathrm{~m}^{3}\right)$ of demolition debris, about $12,000 \mathrm{yd}^{3}\left(9,200 \mathrm{~m}^{3}\right)$ of contaminated soil from the former ore storage area, and about $295,000 \mathrm{yd}^{3}$ $\left(226,000 \mathrm{~m}^{3}\right)$ of windblown and other contaminated material from vicinity properties (DOE, 1994a).

Surface remedial action at the Naturita uranium processing site started in August 1994 and should be completed in 1997. Residual contaminated soils and materials will be transported to Umetco's Burbank disposal site at Uravan (Figure 1.1) and contained in a disposal cell.

After the remedial action, the Naturita site will be backfilled with clean fill material, recontoured to promote suriace drainage, and revegetated (DOE, 1994b). Then the site will be released for development or other uses.

\subsection{SITE STATUS}

The site is currently under active remediation with contaminated material to be hauled to the upper Burbank repository at Uravan, Colorado. Remediation was begun in May 1994 and is scheduled for completion in February 1997. The Final Environmental Assessment (EA) (DOE, 1994a) has been approved and the Final Remedial Action Plan (RAP) (DOE, 1994b) has been submitted for approval. The Baseline Risk Assessment (BLRA) is currently in preparation.

\subsection{SAMPLING PLAN SUMMARY}

The current sampling plan for the Naturita site is to collect ground water and surface water samples semiannually from DOE monitor wells, private wells, and from surface locations along the San Miguel River. Figures 1.3 and 1.4 indicate 


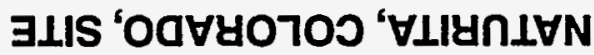

Hd

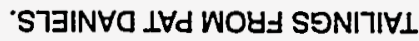
JO NOILYOO 7 NO NOILVWUOJNI

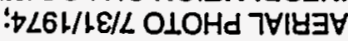

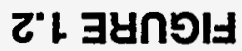

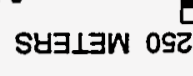

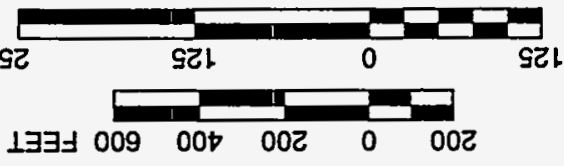

'Hd

$1 \exists \exists \exists 009 \quad 007 \quad 002 \quad 0 \quad 002$

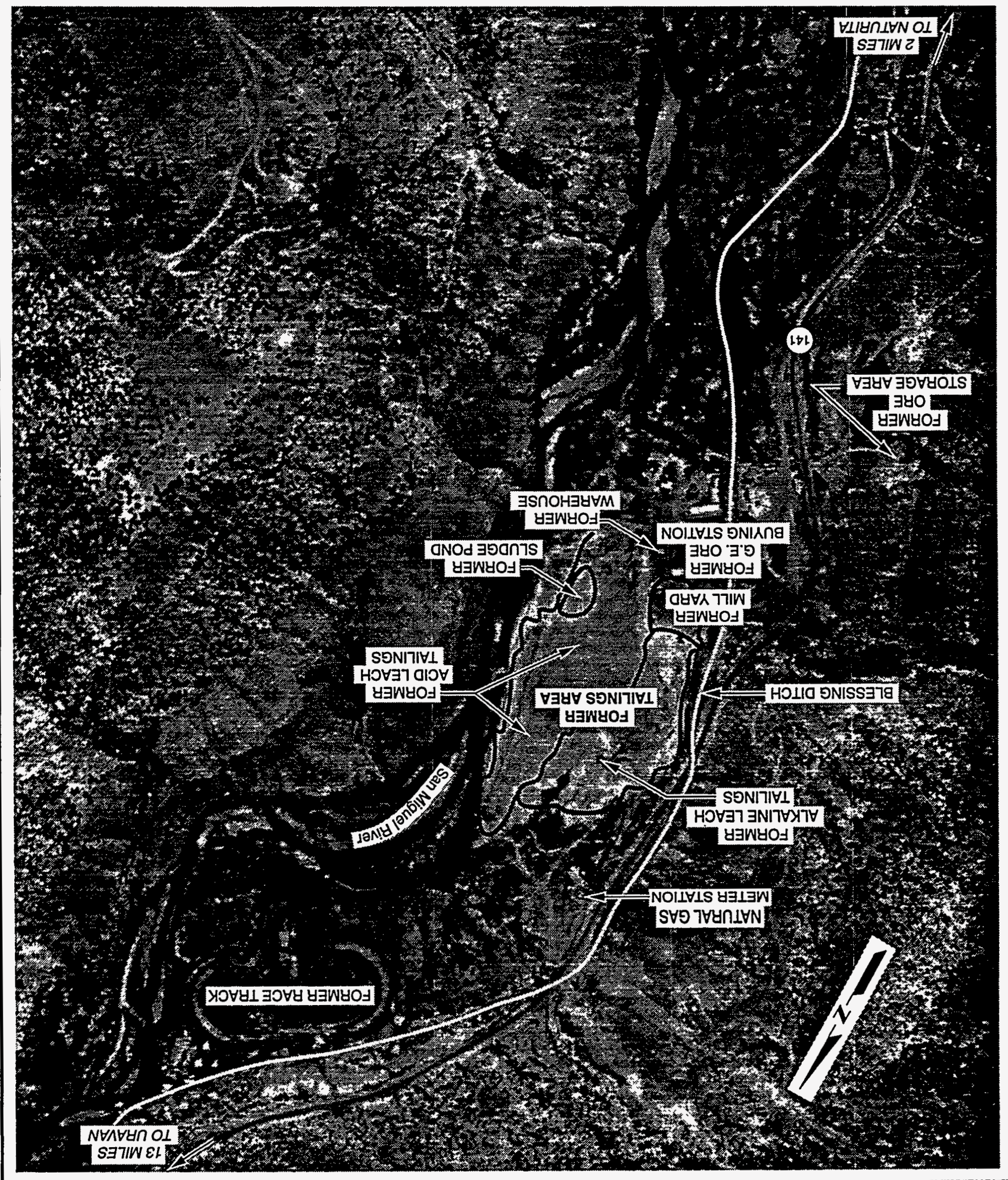




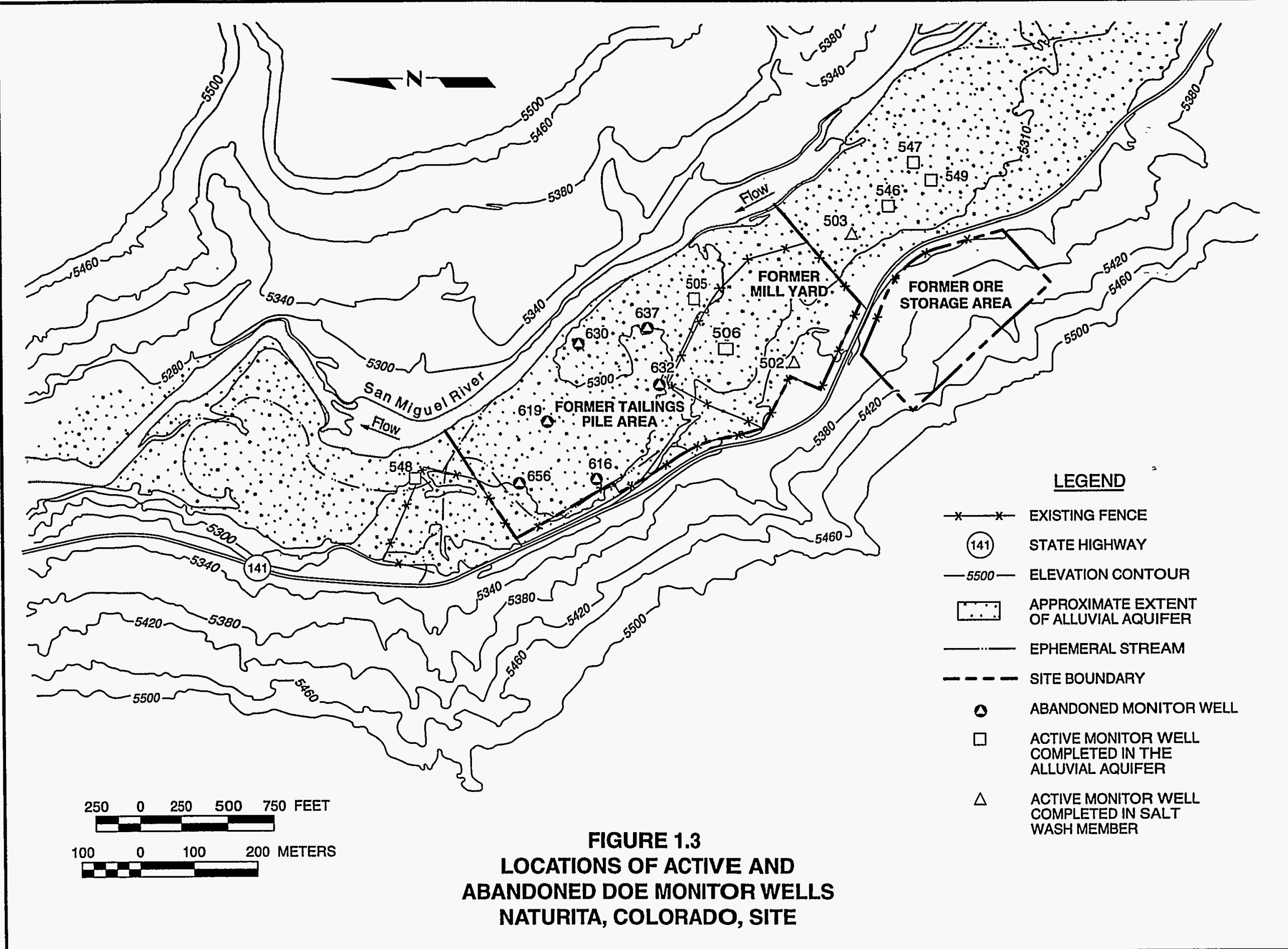




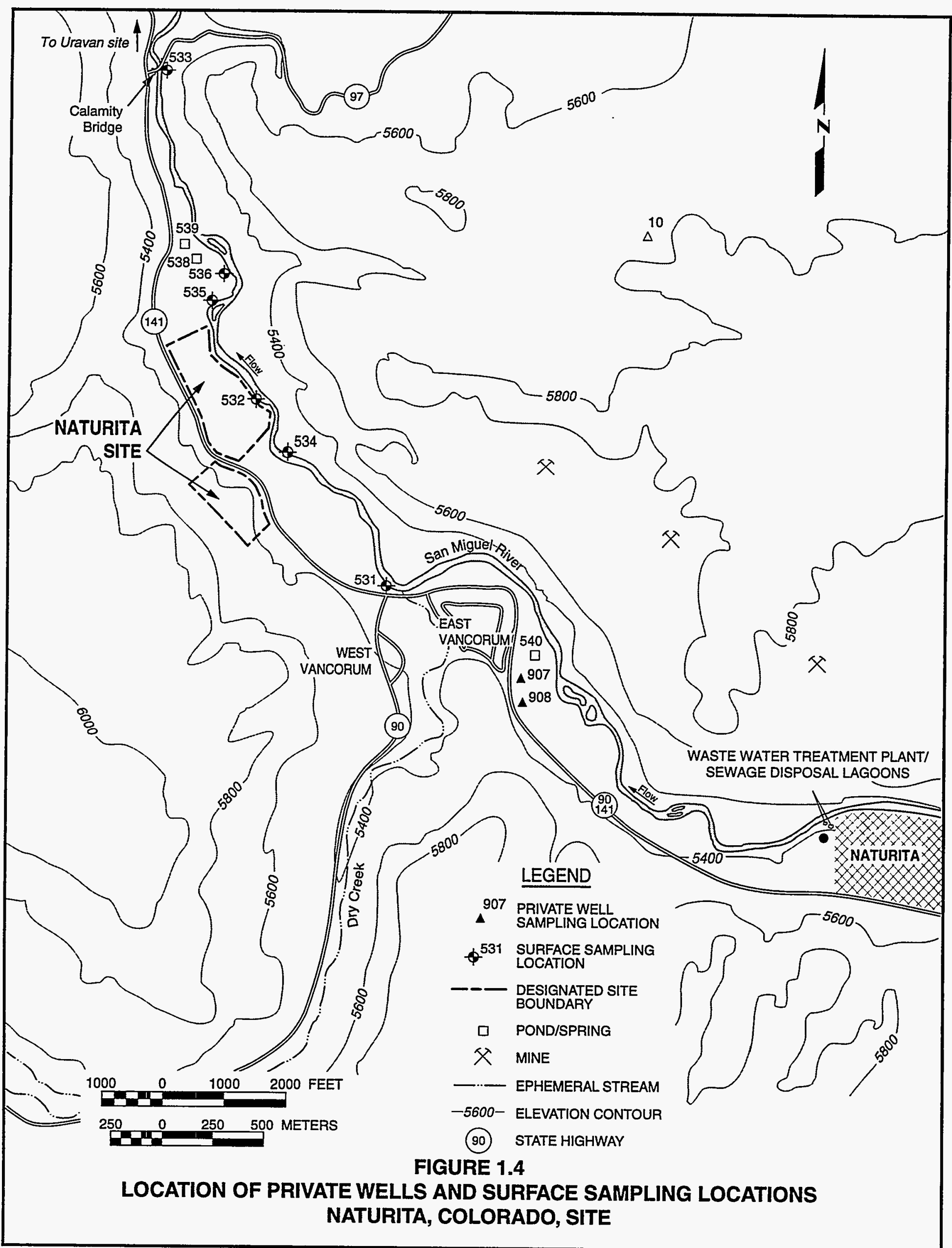


the locations of all site monitor wells, private wells, and surface sampling points. Table 1.1 presents the monitor well completion data for wells in the alluvial aquifer and the Salt Wash Member of the Morrison Formation.

Filtered ground water samples will be analyzed for major elements and field parameters as indicators of general water quality and constituents identified as siterelated contaminants in ground water in accordance with the needs of the BLRA. Unfiltered samples will be analyzed for those metals and radionuclides which may be adsorbed on suspended particulates. Surface water analytes selected for analysis are the same as those for ground water and will be used to monitor the effects of ground water discharge into the San Miguel River and the San Miguel River floodplain.

The analytical parameters for ground water and surface water at the processing site are:

$\begin{array}{llll}\text { Silver* } & \text { Aluminum* } & \text { Arsenic* } & \text { Manganese* } \\ \text { Molybdenum } & \text { Antimony* } & \text { Selenium* } & \text { Vanadium } \\ \text { Uranium* } & \text { Calcium } & \text { Chloride } & \text { Fluoride } \\ \text { Potassium } & \text { Magnesium } & \text { Sodium } & \text { Silica } \\ \text { Sulfate } & \text { Strontium } & \text { Radium-226* } & \text { Radium-228* } \\ \text { Lead-210* } & \text { Polonium-210* Iron* } & \text { Ammonium } \\ \text { Nitrate } & \text { Total Dissolved Solids } & \end{array}$

* Parameters analyzed for in unfiltered samples.

The most recent sampling event at the site occurred in April 1995. The next scheduled water quality sampling round will occur in September 1996 and will include the sites listed in Table 1.2. It is recommended that the proposed sampling plan be implemented semiannually for the next two years and then the data needs should be reassessed and the sampling frequency should be evaluated. 


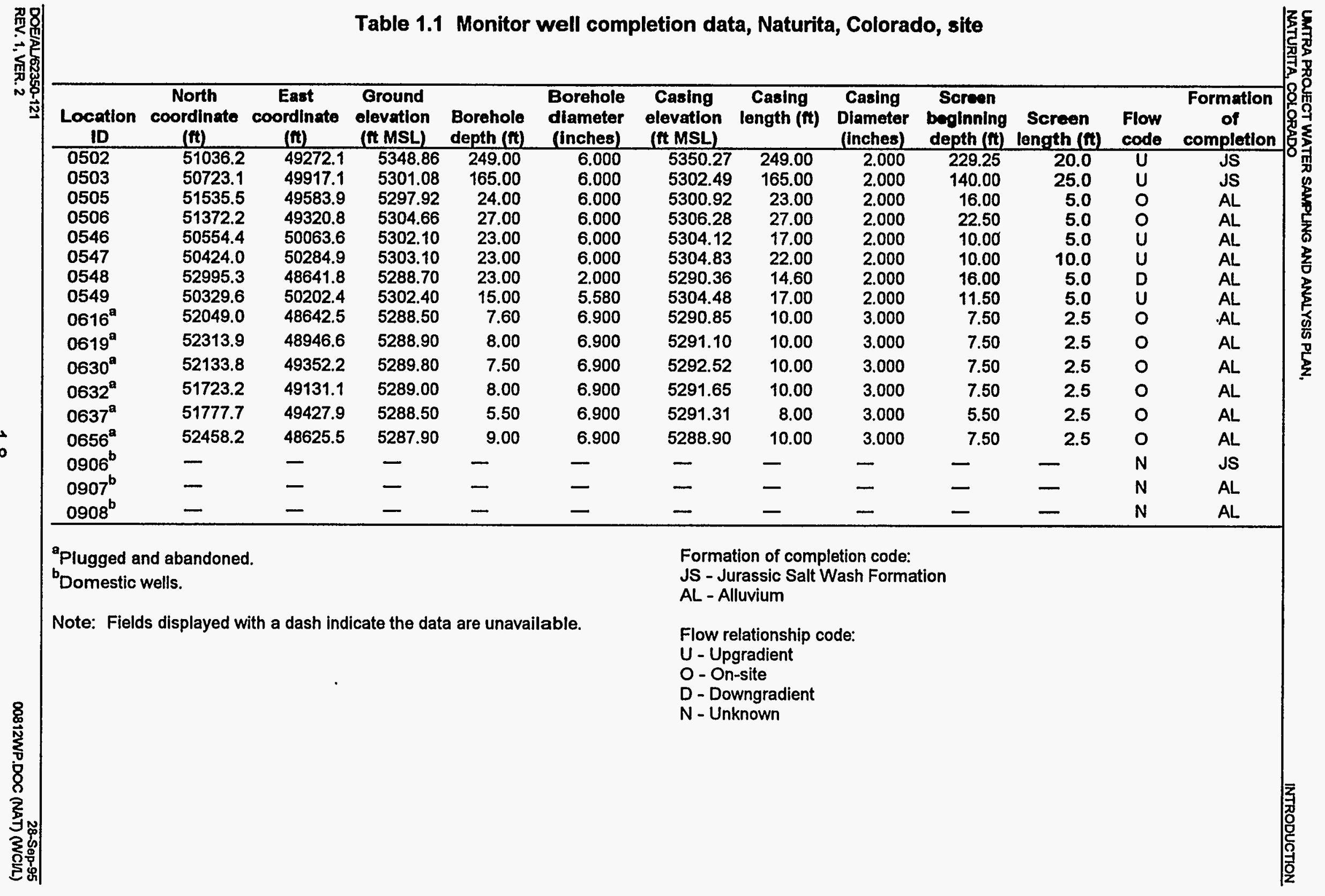


Table 1.2 Sampling locations at the Naturita site

\begin{tabular}{lccl}
\hline & $\begin{array}{c}\text { Ground water } \\
\text { sampling locations }\end{array}$ & & $\begin{array}{c}\text { Surface water } \\
\text { sampling locations }\end{array}$ \\
\hline 907 & Qal - res.bkg & 531 & upstream \\
908 & Qal - res.bkg & 557 & upstream \\
547 & Qal - upgradient & 532 & site \\
546 & Qal - upgradient & 556 & downstream \\
505 & Qal - onsite & 533 & downstream \\
506 & Qal - onsite & 538 & seep \\
548 & . Qal - downgradient & 539 & seep \\
& & 540 & seep \\
\hline
\end{tabular}

Qal $=$ Quaternary alluvium 


\subsection{SITE CONDITIONS}

\section{$2.1 \quad$ SITE BACKGROUND INFORMATION}

\subsubsection{Surrounding land uses}

The Naturita site is in Montrose County, Colorado, about $2 \mathrm{mi}(3 \mathrm{~km})$ northwest of the town of Naturita along Colorado State Highway 141 (Figure 1.1). The 53 acres (ac) (21 hectares [ha]) of the former Naturita processing site include the former tailings area, the mill yard and ore-buying station, and the adjacent ore storage area (Figure 1.2). The former tailings area, which covers about 27 ac (11 ha), is owned by Hecla Mining Corporation (DOE, 1994a). The 14-ac (5.7-ha) mill yard and orebuying station and the 12-ac (4.9-ha) former ore storage area are owned by Cyprus Foote Mineral Company. The ore storage area is adjacent to the former tailings site and west of Colorado State Highway 141. Approximately 6 ac (2 ha) of the former ore storage area are on lands administered by the Bureau of Land Management (BLM) (DOE, 1994a). Remaining site area is on Montrose County-administered lands.

According to Montrose County ordinance, the site is in an agricultural zone (DOE, 1994a) where ranching and farming dominate. Livestock (cattle and horses) grazing is the primary form of agricultural activity in the site region. Hay and corn are the major crops grown in the region (DOE, 1994a).

About 480 people live within the Naturita town limits and there are about 15 families within the area extending approximately $5 \mathrm{mi}(8 \mathrm{~km})$ northwest of the town of Naturita and along Highway 141. Two private properties are northwest of and adjacent to the site, one on each side of the San Miguel River. The land is used for grazing horses, growing household vegetables (tomatoes, potatoes, pepper, com, peas, and beans) and fruit trees (such as cherry, plum, and apricot), and pasture land. The property located on the western side of the river extends approximately $2 \mathrm{mi}(3 \mathrm{~km})$ downstream and along the river and Highway 141. There is a hay field on the portion of the land below the Calamity Bridge (Figure 2.1).

The private land located about $2 \mathrm{mi}(3 \mathrm{~km})$ northwest of the site is used for cattle grazing (DOE, 1994a). The privately owned property located southeast of and adjacent to the site is currently not occupied; however, it appears to be used for equipment storage.

\subsubsection{Surrounding water use}

The San Miguel River water is currently the only source of water for the Naturita water supply system which services the town of Naturita residents and businesses and most of the residents living within the area extending about $5 \mathrm{mi}(8 \mathrm{~km})$ northwest of the town of Naturita (DOE, 1994a). The water intake from the San Miguel River is about $7 \mathrm{mi}(11 \mathrm{~km})$ southeast and upstream of the 


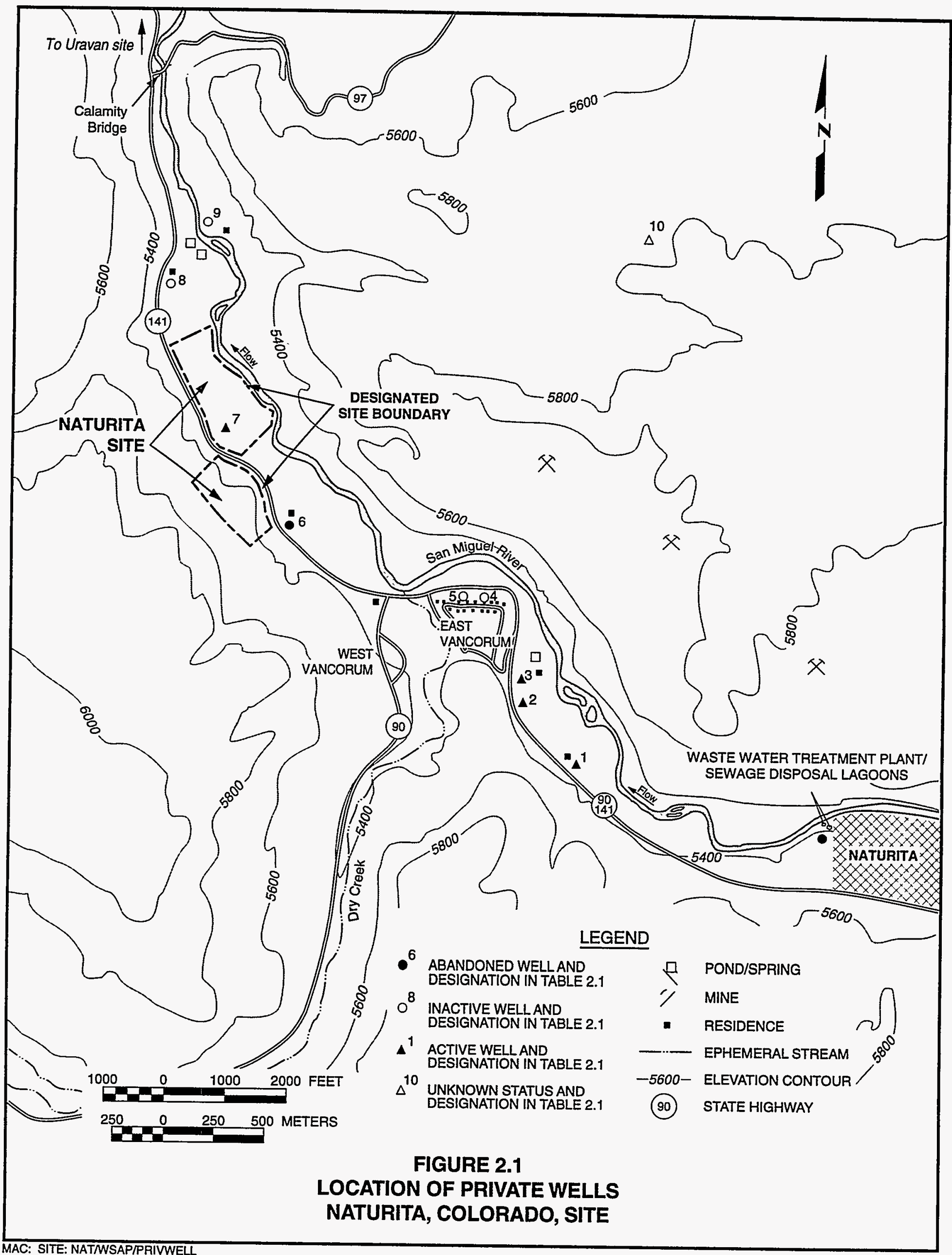


town. A water treatment plant and associated water reservoirs are located immediately near the southem comer of the town. Water treatment consists of sedimentation, filtration, chlorination, and fluoridation. Treated water is pumped to a 500,000-gallon (gal) (2,000,000-liter [L]) water tank and then to water lines which extend to the town limits. The portion of the water which is untreated goes into a ditch channel for agricultural use.

\subsubsection{Contaminant sources}

Salt roasting and alkaline leaching, followed by acid leaching of uranium/ vanadium ores, contributed sodium chloride $(\mathrm{NaCl})$, sodium bicarbonate $\left(\mathrm{NaHCO}_{3}\right)$, sulfuric acid $\left(\mathrm{H}_{2} \mathrm{SO}_{4}\right)$, and ammonium sulfate $\left[\left(\mathrm{NH}_{4}\right)_{2} \mathrm{SO}_{4}\right]$ to the tailings pile, and, thus, to the ground water at the Naturita site. Therefore, indicators of contamination expected in downgradient wells are the sodium $\left(\mathrm{Na}^{+}\right)$, bicarbonate $\left(\mathrm{HCO}_{3}^{-}\right)$, sulfate $\left(\mathrm{SO}_{4}{ }^{2}\right)$, chloride $(\mathrm{Cl})$, and ammonium $\left(\mathrm{NH}_{4}{ }^{+}\right)$ions. Contaminants that can be expected in association with the uranium/vanadium ores themselves include arsenic (As), molybdenum (Mo), selenium (Se), uranium (U), and vanadium $(V)$ (Evans, 1987).

Sources of ground water contamination at the Naturita site include ore, original processing fluids, and tailings. The former tailings pile was removed from the Naturita site in the late 1970 s, thus removing a major source of ground water contamination. The primary sources of contamination remaining include subtailings soil and contaminated soil in the former mill yard. The latter contains tailings used as fill material on the lower mill terrace (DOE, 1995a). The sub-tailings soil contains contaminants that were leached out of the tailings by acidic pore fluids and were subsequently precipitated or adsorbed when acidic solutions were neutralized by naturally occurring carbonate minerals in soils beneath the pile.

\subsection{GEOLOGY AND HYDROLOGY}

\subsubsection{Physical setting}

The Naturita processing site is located in the Canyonlands section of the Colorado Plateau physiographic province (Fenneman, 1946). The Canyonlands section is characterized by deeply incised drainages and isolated mesas. The processing site is within the San Miguel River valley at an elevation of about $5300 \mathrm{ft}(1600 \mathrm{~m})$ above sea level.

The present course of the San Miguel River general coincides with the axis if the Nucla syncline, a major structural feature of the area (Ackerman and Rush, 1984). The Nucla syncline plunges gently to the northwest.

The site is situated on a northwest trending portion of the San Miguel River floodplain and is bordered to the east and northeast by the San Miguel River and to the west and southwest by the northeast flank of Sawtooth Ridge (USGS, 1979). 


\subsubsection{Geology}

Rock units at the Naturita site area consist of a thick sequence of Jurassic continental and marine rocks consisting of sandstone, shale, and limestone. Unconsolidated surficial deposits consist of narrow strips of Quatemary floodplain and river terrace deposits along the incised river valleys. Figure 2.2 shows the regionally significant hydrogeologic units present in the area.

The Naturita processing site is underlain by unconsolidated alluvial deposits and fill material consisting of river gravel and cobbles in a silty to clayey sand matrix. The alluvium ranges in thickness from 11 to $34 \mathrm{ft}(3.4$ to $10 \mathrm{~m})$, with an average thickness of $20 \mathrm{ft}(6 \mathrm{~m})$. The alluvium is underlain by rocks of the Morrison Formation consisting of shales, fine- to very fine-grained sandstones, conglomerates of the Brushy Basin Member, and fine- to coarse-grained sandstones and shales of the Salt Wash Member. The Brushy Basin Member has a maximum thickness of $490 \mathrm{ft}(150 \mathrm{~m})$. At the site, the top of the Salt Wash Member is encountered at depths of 130 to $165 \mathrm{ft}(40$ to $50 \mathrm{~m})$ below ground surface. These units dip 2 to 4 degrees to the northeast.

\subsubsection{Ground water hydrology}

\section{Alluvial Aquifer}

At the processing site, unconfined ground water occurs in the alluvium at depths ranging from 3 to $18 \mathrm{ft}$ ( 1 to $5.5 \mathrm{~m}$ ) below ground surface. Currently, there are six monitor wells completed within the alluvial aquifer at the site. Monitor wells 546, 547, and 549 monitor upgradient locations; monitor wells 505 and 506 are located in the former tailings pile and mill yard areas respectively, and monitor well 548 is located downgradient of the former tailings pile area. In late 1992, six monitor wells $(616,619,630,632,637$, and 656) were removed or destroyed prior to the initiation of surface remedial action. Figure 2.3 shows the locations of active and abandoned monitor wells at the site.

To aid in the assessment of potential points of exposure via ground water use, it is important to understand the configuration of the alluvial aquifer and the interaction between ground water and surface water. The general configuration of the alluvial aquifer is controlled by the depositional extent and saturated thickness of the alluvium within the San Miguel River drainage.

To the west, the aquifer is bounded by the rocks of the Brushy Basin Member, which forms the lower canyon wall and generally may be regarded as a no-flow boundary. To the east and north of the site, the San Miguel River dissects the valley alluvium and probably constitutes a hydrologic boundary for the aquifer based on the depth of channel incisement and the seasonal interaction between surface water and ground water. During periods of high river stage, the alluvial aquifer is recharged by the river along the eastern boundary of the site. 


\begin{tabular}{|c|c|c|c|c|}
\hline $\begin{array}{l}\text { SYSTEM } \\
\text { OR SERIES }\end{array}$ & $\begin{array}{l}\text { ROCK } \\
\text { UNIT }\end{array}$ & $\begin{array}{l}\text { MAXIMUM } \\
\text { THICKNESS } \\
\text { (feet/meters) }\end{array}$ & $\begin{array}{l}\text { PREDOMINANT } \\
\text { LITHOLOGY }\end{array}$ & $\begin{array}{c}\text { HYDROGEOLOGIC } \\
\text { UNIT }\end{array}$ \\
\hline Quaternary & Alluvium & $49 / 15$ & $\begin{array}{l}\text { Silt, sand and gravel } \\
\text { associated with } \\
\text { floodplain and } \\
\text { river terrace }\end{array}$ & $\begin{array}{l}\text { Quaternary } \\
\text { alluvial aquifer }\end{array}$ \\
\hline $\begin{array}{l}\text { Upper } \\
\text { Jurassic }\end{array}$ & $\begin{array}{c}\text { Brushy Basin } \\
\text { Member } \\
\text { Salt Wash } \\
\text { Member }\end{array}$ & $\begin{array}{l}490 / 150 \\
360 / 110\end{array}$ & $\begin{array}{l}\text { Shale, sandstone, } \\
\text { and conglomerate } \\
\text { Sandstone } \\
\text { and shale }\end{array}$ & $\begin{array}{l}\text { Mesozoic } \\
\text { sandstone } \\
\text { aquifer }\end{array}$ \\
\hline
\end{tabular}

MODIFIED FROM ACKERMAN AND RUSH, 1984.

FIGURE 2.2

ROCKS AND HYDROGEOLOGIC UNITS PRESENT IN THE AREA

NATURITA, COLORADO, SITE 


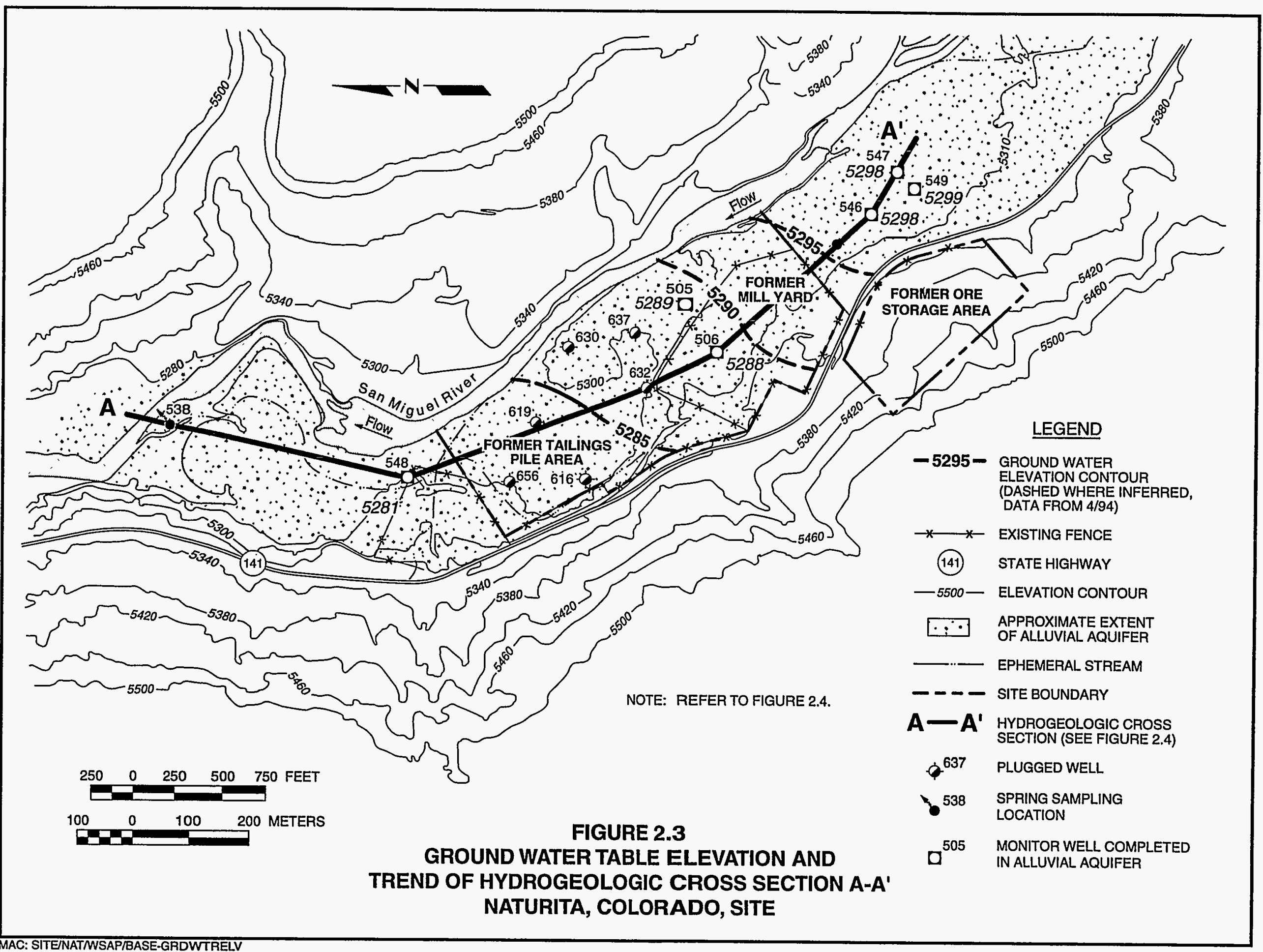


Conversely, during periods of low river stage, water in the alluvial aquifer probably discharges to the river channel. North of the site, the river channel trends northwest, crossing from the east side to the west side of the drainage and bisecting the alluvium down stream of the site. This configuration creates a natural discharge zone for the alluvial aquifer.

Information obtained from the installation of six site monitor wells that fully penetrate the alluvial aquifer indicates that the saturated thickness of the alluvial aquifer varies from about 6 to $10 \mathrm{ft}(2$ to $3 \mathrm{~m})$ in the southem portion of the site near wells 549 and 546 , to about $14 \mathrm{ft}(4.2 \mathrm{~m})$ north of the former tailings pile area near well 548. In the central portion of the site, the saturated thickness of the alluvial aquifer is observed to be about $10 \mathrm{ft}(3 \mathrm{~m})$ at well 506 and $11 \mathrm{ft}(3.3 \mathrm{~m})$ at well 505.

Surface water and ground water interaction north of the site is of interest due to the potential for underflow of ground water beneath the river. The potential for underflow must be assessed to accurately determine potential points of exposure downgradient of the site. Underflow may occur where a significant portion of the alluvial aquifer is present beneath the river channel. North of the former processing site, the vertical extent of river channel incisement in the alluvium is unknown. However, it is doubtful that the channel completely bisects the alluvium. The presence of a spring (538) near the river channel indicates that ground water discharges to the river in the area. However, it is likely that underflow is also present where the alluvial aquifer is present beneath the river channel.

The measured horizontal hydraulic gradient within the alluvium is 0.005 , based on water level measurements made in monitor wells 548 and 549 in April 1994. Figure 2.3 is a ground water table elevation map for the site and Figure 2.4 is a hydrogeologic cross section of the site.

The average measured hydraulic conductivity value of the alluvial aquifer, as determined from slug tests, is $3.0 \mathrm{ft}$ per day $(0.001$ centimeters [cm] per second) (DOE 1994b; calculation number NAT-06-89-14-02-00). The accuracy of slug test data is affected by a variety of factors (well efficiency, test duration, the radius of influence of the test). Consequently, hydraulic conductivity values, as measured by slug tests, are commonly underestimated by one order of magnitude and can be underestimated by as much as two orders of magnitude. Therefore, the actual hydraulic conductivity of the alluvial aquifer may range from $3.0 \mathrm{ft}$ per day $(0.001 \mathrm{~cm}$ per second) to $300 \mathrm{ft}$ per day $(0.1 \mathrm{~cm}$ per second).

Based on the estimated range of hydraulic conductivity, field measured values of hydraulic gradient and an estimated effective porosity of 0.25 , the linear ground water flow velocity likely ranges from 20 to $200 \mathrm{ft}(6$ to $60 \mathrm{~m})$ per year, and may possibly be as high as $2000 \mathrm{ft}(600 \mathrm{~m})$ per year (DOE, 1994b; calculation number NAT-08-89-14-07-0). 


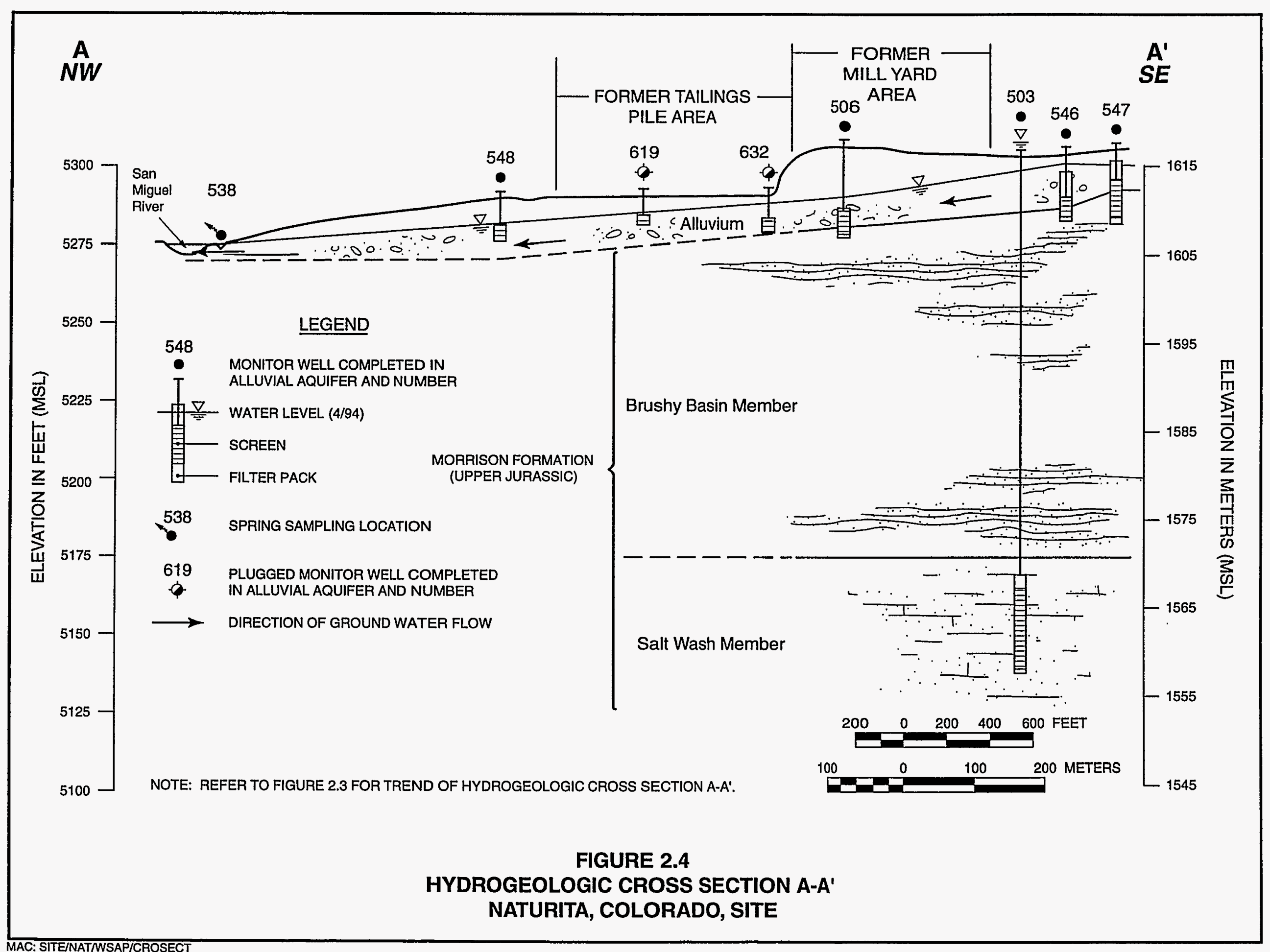


Ground water recharge and discharge zones for the alluvial aquifer are generally established relative to the gradient of the San Miguel River. Upstream of the site, the alluvial aquifer is recharged by inflow from the river, and downstream of the site, the alluvial aquifer discharges to the river.

\section{Bedrock Aquifer}

The Brushy Basin Member and the Salt Wash Member of the Morrison Formation are part of the regionally significant Mesozoic sandstone aquifer (Weir et al, 1984). While the Brushy Basin and Salt Wash Members are considered collectively to be part of the Mesozoic sandstone aquifer from a regional standpoint, they must be treated separately with respect to the Naturita processing site due to the distinctly unique hydraulic properties for each unit. The Brushy Basin Member is the uppermost bedrock unit at the site and consists of interbedded shale, sandstone, and conglomerate lenses. The Brushy Basin Member is estimated to range from 110 to $165 \mathrm{ft}$ ( 36 to $50 \mathrm{~m}$ ) thick. Drilling performed in 1985 to install monitor wells at the site indicated that the Brushy Basin Member is generally not a source of ground water beneath the site. Lithologically, the unit is primarily composed of low permeability shale and mudstone. During the drilling of monitor well 502 (total depth $249 \mathrm{ft}[76 \mathrm{~m}])$, the occurrence of ground water was noted at $155 \mathrm{ft}(47 \mathrm{~m})$ below ground surface, within $10 \mathrm{ft}(3 \mathrm{~m})$ of the estimated contact with the lower Salt Wash Member. Subsequent water level measurements for this monitor well consistently note a piezometric head rising to within approximately $50 \mathrm{ft}(20 \mathrm{~m})$ of the land surface. Given the completion interval for this well, 220 to $249 \mathrm{ft}$ (70 to $76 \mathrm{~m}$ ) below ground surface within the Salt Wash Member, it is apparent that the Brushy Basin Member serves to confine ground water present in the Salt Wash Member.

Beneath the processing site, the Salt Wash Member consists of sandstone with some shale. Two monitor wells, 502 and 503, are completed in the Salt Wash Member. The average hydraulic conductivity for the Salt Wash Member, as determined from slug tests, is $0.06 \mathrm{ft}$ per day $\left(2 \times 10^{-5} \mathrm{~cm}\right.$ per second) and the horizontal hydraulic gradient is approximately 0.003 , with ground water flow to the northeast along preferential bedding of the bedrock strata (DOE, 1994b).

A preliminary estimate of ground water flow velocity for the bedrock aquifer can be made, based on an estimate of the range of hydraulic conductivity (using the field measured average as the lower bound and the field measured average plus one or two orders of magnitude as the upper bound), field measured values of hydraulic gradient, and an estimated effective porosity of 0.10 . The resulting likely value for linear ground water flow velocity ranges from $0.7 \mathrm{ft}$ to $7 \mathrm{ft}(0.2 \mathrm{~m}$ to $2 \mathrm{~m})$ per year and may be as high as $70 \mathrm{ft}(20 \mathrm{~m})$ per year (DOE, 1994b; calculation number NAT08-89-14-07-00).

The vertical gradient between the alluvial aquifer and the Salt Wash is 0.04 in an upward direction (DOE, 1994b). The upward vertical hydraulic gradient of ground water in the Salt Wash and the thickness and low permeability characteristics of the Brushy Basin indicate that the alluvial aquifer may be recharged by upward leakage 
from the Salt Wash Member; downward flow from the alluvial aquifer to the Salt Wash Member does not occur.

\subsubsection{Surface water hydrology}

The Naturita processing site is located on the west bank of the San Miguel River, which flows in a northwesterly direction through San Miguel Canyon. The San Miguel River originates in the San Juan Mountains near Telluride, Colorado, and joins the Dolores River $20 \mathrm{mi}(30 \mathrm{~km})$ downstream from the town of Naturita. In the vicinity of the processing site, the San Miguel River has a drainage area of 1209 square miles $\left(\mathrm{mi}^{2}\right)$ (3131 square kilometers $\left.\left[\mathrm{km}^{2}\right]\right)(D O E, 1994 \mathrm{~b})$.

A U. S. Geological Survey (USGS) gauging station was located on the San Miguel River near the town of Naturita, $3 \mathrm{mi}(5 \mathrm{~km})$ upstream of the site from 1918 until 1981. During the years 1930 through 1940, data were not recorded for this location. Consequently, the period of record for surface water stage and discharge at Naturita encompass 53 years of measurements. In order to assess the distribution of low flow conditions for the San Miguel River at Naturita, a statistical analysis of the available historical data was performed (DOE, 1995a). For the low flow analysis, the low normal monthly mean values for discharge for each year were compiled. The results indicate the mean annual monthly flow value is about $60 \mathrm{ft}^{3}$ $\left(1.7 \mathrm{~m}^{3}\right)$ per second and the fifth percentile value is about $20 \mathrm{ft}^{3}\left(0.6 \mathrm{~m}^{3}\right)$ per second. The fifth percentage corresponds to the approximate value of a low flow event having a probability of occurring once every twenty years.

The former tailings pile and mill yard areas are located approximately $650 \mathrm{ft}(200 \mathrm{~m})$ from the San Miguel River and approximately 31 ac (13 ha) of the site is within the 100-year floodplain of the San Miguel River (DOE, 1994b). Unnamed ephemeral streams drain the uplands to the west and transect the site north and west of the former tailings pile area (see Figure 2.3). An unnamed spring (surface water sample location 538) is located near the extreme northwest portion of the alluvial floodplain. This spring is a point of discharge for ground water from the alluvial aquifer.

\subsection{WATER QUALITY}

\subsubsection{Background water quality}

Background water quality is defined as the quality of ground water that would be present at the site if uranium milling activities had not taken place. Upgradient alluvial monitor wells 547 and 549 are located in an area containing a minor amount of wind-blown contamination on the land surface (Figure 2.3). These wells have had maximum uranium concentrations in ground water of 0.025 milligrams per liter $(\mathrm{mg} / \mathrm{L})$ and a maximum measured activity of radium-226 plus radium-228 of 6.8 picocuries per liter (pCi/L).

These values are within the range of natural background values measured for mill tailings sites having a similar hydrologic setting (DOE, 1995b). Uranium and radium 
in these wells could come from natural sources. The Salt Wash Member beneath the site is a known uranium ore body, and the Brushy Basin Member, lying directly beneath the alluvium, is known to contain uranium ore in nearby regions (Brod and Stone, 1981). Nevertheless, monitor wells 547 and 549 will be treated as an upper bound on background rather than natural background. Thus, natural background water may have lower levels of some constituents than are observed in monitor wells 547 and 549.

Ground water in alluvial monitor wells 547 and 549 is classified as a calcium sulfate type (Figure 2.5) and the $\mathrm{pH}$ ranges from 6.84 to 7.32 . Total dissolved solids (TDS) range from 568 to $2520 \mathrm{mg} / \mathrm{L}$ and the alkalinity (as $\mathrm{mg} / \mathrm{L} \mathrm{CaCO}$ ) ranges from 211 to 268. Most trace elements were detected at low concentrations or were never detected in analyses of ground water in these wells. However, in addition to uranium and radium, other trace elements that were historically present are fluoride (up to $0.57 \mathrm{mg} / \mathrm{L}$ ), strontium (up to $1.96 \mathrm{mg} / \mathrm{L}$ ), and sulfide (up to $2.3 \mathrm{mg} / \mathrm{L}$ ). Phosphate has been as high as $1.0 \mathrm{mg} / \mathrm{L}$ and nitrate values as high as $12.5 \mathrm{mg} / \mathrm{L}$ (as $\mathrm{NO}_{3}$ ) have been observed. Phosphate and nitrate values may be related to agricultural activities in the area.

\subsubsection{Point of compliance}

At this time, there are no points of compliance at the Naturita, Colorado, UMTRA site.

\subsubsection{Contaminant delineation}

Ground water quality data from the Naturita uranium processing site, collected from 1989 through 1994, are used to characterize the magnitude and extent of contamination. This allows for incorporation of 5 years of ground water data representing the most recent information on current site conditions. A statistical summary of background and downgradient ground water quality analyses is presented in Table 2.1.

Chloride is a primary indicator of processing chemicals at the site and it is largely unaffected by precipitation and adsorption reactions. A chloride isopleth map (Figure 2.6) shows that remaining high chloride concentrations are confined to an elongate area in the alluvium underlying the western half of the former tailings pile. Ground water underlying the eastem half of the former tailings pile, closest to the river, has chloride concentrations at or below those found in background wells. This distribution is the result of alkaline leach tailings that were deposited on the western half of the site (DOE, 1995a). 


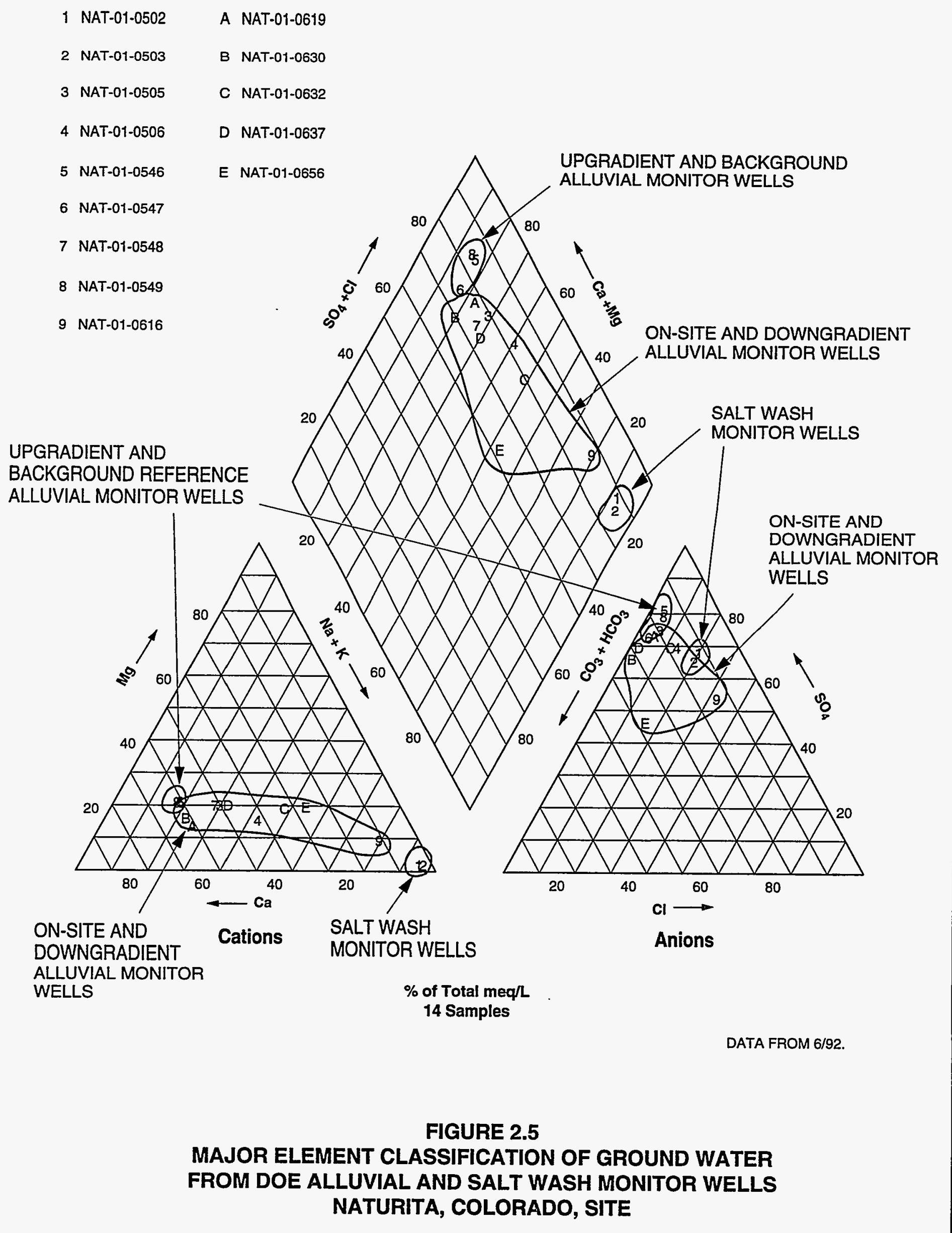


Table 2.1 Comparison of background and on-site ground water quality in the alluvial aquifer and downgradient spring water quality, Naturita, Colorado, site

\begin{tabular}{|c|c|c|c|c|c|}
\hline Constituent & Well ID' & $\begin{array}{l}\text { Frequency } \\
\text { of detection }^{\text {b }}\end{array}$ & $\begin{array}{c}\text { Minimum } \\
(\mathrm{mg} / \mathrm{L})\end{array}$ & $\begin{array}{c}\text { Median } \\
\text { (mg/L) }\end{array}$ & $\begin{array}{c}\text { Maximum } \\
\text { (mg/L) }\end{array}$ \\
\hline $\begin{array}{l}\text { Inorganics } \\
\text { Aluminum }^{\circ}\end{array}$ & & & & & \\
\hline $\begin{array}{l}\text { Background } \\
\text { On-site } \\
\text { Spring }\end{array}$ & 538 & $\begin{array}{c}2 / 14 \\
6 / 13 \\
0 / 0\end{array}$ & $\begin{array}{l}<0.05 \\
<0.05 \\
\text { NA }\end{array}$ & $\begin{array}{l}<0.09 \\
<0.10 \\
\text { NA }\end{array}$ & $\begin{array}{l}0.13 \\
0.28 \\
\text { NA }\end{array}$ \\
\hline $\begin{array}{l}\text { Ammonium }{ }^{\mathrm{d}, \mathrm{e}} \\
\text { Background } \\
\text { On-site } \\
\text { Spring }\end{array}$ & 538 & $\begin{array}{l}4 / 12 \\
7 / 11 \\
0 / 0\end{array}$ & $\begin{array}{l}0.09 \\
<0.10 \\
N A\end{array}$ & $\begin{array}{l}<0.10 \\
0.26 \\
\text { NA }\end{array}$ & $\begin{array}{l}0.14 \\
1.4 \\
\text { NA }\end{array}$ \\
\hline $\begin{array}{l}\text { Antimony }{ }^{\ominus} \\
\text { Background } \\
\text { On-site } \\
\text { Spring }\end{array}$ & 538 & $\begin{array}{c}0 / 15 \\
5 / 13 \\
0 / 1\end{array}$ & $\begin{array}{l}<0.003 \\
<0.003 \\
N A\end{array}$ & $\begin{array}{l}<0.003 \\
<0.003 \\
<0.003\end{array}$ & $\begin{array}{l}<0.020 \\
0.043 \\
N A\end{array}$ \\
\hline $\begin{array}{l}\text { Arsenic }^{\circ} \\
\text { Background } \\
\text { On-site } \\
\text { Spring }\end{array}$ & 538 & $\begin{array}{c}0 / 15 \\
11 / 13 \\
0 / 1\end{array}$ & $\begin{array}{l}<0.001 \\
0.007 \\
\text { NA }\end{array}$ & $\begin{array}{l}<0.01 \\
0.03 \\
<0.005\end{array}$ & $\begin{array}{l}<0.01 \\
0.08 \\
\text { NA }\end{array}$ \\
\hline $\begin{array}{l}\text { Barium } \\
\text { Background } \\
\text { On-site } \\
\text { Spring }\end{array}$ & 538 & $\begin{array}{l}6 / 14 \\
7 / 13 \\
0 / 0\end{array}$ & $\begin{array}{l}0.02 \\
0.04 \\
\text { NA }\end{array}$ & $\begin{array}{l}<0.1 \\
<0.1 \\
N A\end{array}$ & $\begin{array}{l}<0.1 \\
<0.2 \\
\text { NA }\end{array}$ \\
\hline $\begin{array}{l}\text { Beryllium } \\
\text { Background } \\
\text { On-site } \\
\text { Spring }\end{array}$ & 538 & $\begin{array}{l}0 / 10 \\
0 / 9 \\
0 / 0\end{array}$ & $\begin{array}{l}<0.005 \\
<0.005 \\
\text { NA }\end{array}$ & $\begin{array}{l}<0.005 \\
<0.005 \\
N A\end{array}$ & $\begin{array}{l}<0.01 \\
<0.01 \\
\text { NA }\end{array}$ \\
\hline $\begin{array}{l}\text { Boron } \\
\text { Background } \\
\text { On-site } \\
\text { Spring }\end{array}$ & 538 & $\begin{array}{l}0 / 4 \\
4 / 4 \\
0 / 0\end{array}$ & $\begin{array}{l}<0.1 \\
0.2 \\
N A\end{array}$ & $\begin{array}{l}<0.1 \\
0.2 \\
N A\end{array}$ & $\begin{array}{l}<0.1 \\
0.3 \\
N A\end{array}$ \\
\hline $\begin{array}{l}\text { Bromide } \\
\text { Background } \\
\text { On-site } \\
\text { Spring } \\
\end{array}$ & 538 & $\begin{array}{l}0 / 5 \\
3 / 4 \\
0 / 1 \\
\end{array}$ & $\begin{array}{l}<0.1 \\
<0.1 \\
N A\end{array}$ & $\begin{array}{l}<0.1 \\
0.4 \\
<0.10\end{array}$ & $\begin{array}{l}<2.0 \\
0.6 \\
N A\end{array}$ \\
\hline
\end{tabular}


Table 2.1 Comparison of background and on-site ground water quality in the alluvial aquifer and downgradient spring water quality, Naturita, Colorado, site (Continued)

\begin{tabular}{|c|c|c|c|c|c|}
\hline Constituent & Well ID" & $\begin{array}{l}\text { Frequency } \\
\text { of detection }\end{array}$ & $\begin{array}{l}\text { Minimum } \\
\text { (mg/L) }\end{array}$ & $\begin{array}{l}\text { Medianc } \\
\text { (mg/L) }\end{array}$ & $\begin{array}{l}\text { Maximum } \\
\text { (mg/L) }\end{array}$ \\
\hline \multicolumn{6}{|l|}{ Cadmium } \\
\hline Background & & $1 / 14$ & $<0.001$ & $<0.001$ & 0.001 \\
\hline On-site & & $3 / 13$ & $<0.001$ & $<0.001$ & 0.002 \\
\hline Spring & 538 & $0 / 0$ & NA & NA & NA \\
\hline \multicolumn{6}{|l|}{ Calcium ${ }^{\circ}$} \\
\hline Background & & $15 / 15$ & 98 & 155 & 251 \\
\hline On-site & 632 & $7 \pi$ & 210 & 243 & 281 \\
\hline Spring & 538 & $1 / 1$ & NA & 170 & NA \\
\hline \multicolumn{6}{|l|}{ Chloride $^{\theta}$} \\
\hline Background & & $15 / 15$ & 2.2 & 8.2 & 16 \\
\hline On-site & 616 & $6 / 6$ & 419 & 546 & 856 \\
\hline Spring & 538 & $1 / 1$ & NA & 7.4 & NA \\
\hline \multicolumn{6}{|l|}{ Chromium } \\
\hline Background & & $0 / 12$ & $<0.01$ & $<0.01$ & $<0.01$ \\
\hline On-site & & $0 / 11$ & $<0.01$ & $<0.01$ & $<0.01$ \\
\hline Spring & 538 & $0 / 0$ & NA & NA & NA \\
\hline \multicolumn{6}{|l|}{ Cobalt } \\
\hline Background & & $0 / 4$ & $<0.05$ & $<0.05$ & $<0.05$ \\
\hline On-site & & $0 / 4$ & $<0.05$ & $<0.05$ & $<0.05$ \\
\hline Spring & 538 & $0 / 0$ & NA & NA & NA \\
\hline \multicolumn{6}{|l|}{ Copper } \\
\hline Background & & $0 / 10$ & $<0.01$ & $<0.02$ & $<0.02$ \\
\hline On-site & & $0 / 9$ & $<0.01$ & $<0.02$ & $<0.02$ \\
\hline Spring & 538 & $0 / 0$ & NA & NA & NA \\
\hline \multicolumn{6}{|l|}{ Cyanide } \\
\hline Background & & $0 / 14$ & $<0.01$ & $<0.01$ & $<0.02$ \\
\hline On-site & & $0 / 13$ & $<0.01$ & $<0.01$ & $<0.02$ \\
\hline Spring & 538 & $0 / 0$ & NA & NA & NA \\
\hline \multicolumn{6}{|l|}{ Fluoride ${ }^{\circ}$} \\
\hline Background & & $15 / 15$ & 0.30 & 0.30 & 0.57 \\
\hline On-site & 616 & $6 / 6$ & 1.0 & 1.4 & 1.6 \\
\hline Spring & 538 & $1 / 1$ & NA & 0.20 & NA \\
\hline
\end{tabular}


Table 2.1 Comparison of background and on-site ground water quality in the alluvial aquifer and downgradient spring water quality, Naturita, Colorado, site (Continued)

\begin{tabular}{|c|c|c|c|c|c|}
\hline Constituent & Well ID* & $\begin{array}{l}\text { Frequency } \\
\text { of detection }^{b}\end{array}$ & $\begin{array}{c}\text { Minimum } \\
\text { (mg/L) }\end{array}$ & $\begin{array}{c}\text { Medianc } \\
\text { (mg/L) }\end{array}$ & $\begin{array}{c}\text { Maximum } \\
(\mathrm{mg} / \mathrm{L})\end{array}$ \\
\hline \multicolumn{6}{|l|}{ Iron } \\
\hline Background & & $2 / 5$ & $<0.03$ & $<0.03$ & 0.08 \\
\hline On-site & & $2 / 4$ & $<0.03$ & $<0.05$ & 0.09 \\
\hline Spring & 538 & $1 / 1$ & NA & 0.27 & NA \\
\hline \multicolumn{6}{|l|}{ Lead } \\
\hline Background & & $0 / 10$ & $<0.005$ & $<0.01$ & $<0.01$ \\
\hline On-site & & $0 / 9$ & $<0.005$ & $<0.01$ & $<0.01$ \\
\hline Spring & 538 & $0 / 0$ & NA & NA & NA \\
\hline \multicolumn{6}{|l|}{ Magnesium ${ }^{\circ}$} \\
\hline Background & & $15 / 15$ & 24 & 32 & 49 \\
\hline On-site & 632 & $7 / 7$ & 70 & 89 & 97 \\
\hline Spring & 538 & $1 / 1$ & NA & 39 & NA \\
\hline \multicolumn{6}{|l|}{ Manganese $^{\bullet}$} \\
\hline Background & & $6 / 15$ & $<0.01$ & $<0.01$ & 0.05 \\
\hline On-site & 656 & $6 / 6$ & 1.9 & 5.1 & 7.5 \\
\hline Spring & 538 & $1 / 1$ & NA & 0.98 & NA \\
\hline \multicolumn{6}{|l|}{ Mercury } \\
\hline Background & & $0 / 10$ & $<0.0002$ & $<0.0002$ & $<0.0002$ \\
\hline On-site & & $0 / 9$ & $<0.0002$ & $<0.0002$ & $<0.0002$ \\
\hline Spring & 538 & $0 / 0$ & NA & NA & NA \\
\hline \multicolumn{6}{|l|}{ Molybdenum ${ }^{\circ}$} \\
\hline Background & & $3 / 15$ & $<0.01$ & $<0.01$ & 0.03 \\
\hline On-site & 616 & $6 / 6$ & 0.25 & 0.29 & 0.38 \\
\hline Spring & 538 & $1 / 1$ & NA & 0.01 & NA \\
\hline \multicolumn{6}{|l|}{ Nickel } \\
\hline Background & & $0 / 10$ & $<0.04$ & $<0.04$ & $<0.04$ \\
\hline On-site & & $0 / 9$ & $<0.04$ & $<0.04$ & $<0.04$ \\
\hline Spring & 538 & 0.0 & NA & NA & NA \\
\hline \multicolumn{6}{|l|}{ Nitrate $^{\circ}$} \\
\hline Background & & $8 / 14$ & $<0.01$ & 1.7 & 13 \\
\hline On-site & & $10 / 13$ & $<0.1$ & 2.7 & 45 \\
\hline Spring & 538 & $1 / 1$ & NA & 3.8 & NA \\
\hline
\end{tabular}


Table 2.1 Comparison of background and on-site ground water quality in the alluvial aquifer and downgradient spring water quality, Naturita, Colorado, site (Continued)

\begin{tabular}{|c|c|c|c|c|c|}
\hline Constituent & Well IDa & $\begin{array}{l}\text { Frequency } \\
\text { of detection }\end{array}$ & $\begin{array}{c}\text { Minimum } \\
\text { (mg/L) }\end{array}$ & $\begin{array}{c}\text { Median } \\
\text { (mg/L) }\end{array}$ & $\begin{array}{c}\text { Maximum } \\
\text { (mglL) }\end{array}$ \\
\hline \multicolumn{6}{|l|}{ Phosphate $^{\theta}$} \\
\hline $\begin{array}{l}\text { Background } \\
\text { On-site } \\
\text { Spring }\end{array}$ & 538 & $\begin{array}{c}6 / 14 \\
10 / 12 \\
0 / 0\end{array}$ & $\begin{array}{l}<0.1 \\
<0.1 \\
N A\end{array}$ & $\begin{array}{l}<0.1 \\
0.4 \\
N A\end{array}$ & $\begin{array}{l}1.0 \\
0.6 \\
\text { NA }\end{array}$ \\
\hline \multicolumn{6}{|l|}{ Potassium ${ }^{\circ}$} \\
\hline $\begin{array}{l}\text { Background } \\
\text { On-site } \\
\text { Spring }\end{array}$ & $\begin{array}{l}632 \\
538\end{array}$ & $\begin{array}{l}13 / 15 \\
7 / 7 \\
0 / 0\end{array}$ & $\begin{array}{l}1.0 \\
31 \\
N A\end{array}$ & $\begin{array}{l}1.9 \\
41 \\
\text { NA }\end{array}$ & $\begin{array}{l}2.8 \\
48 \\
N A\end{array}$ \\
\hline \multicolumn{6}{|l|}{ Selenium $^{\mathrm{d}, e}$} \\
\hline $\begin{array}{l}\text { Background } \\
\text { On-site } \\
\text { Spring }\end{array}$ & 538 & $\begin{array}{c}3 / 14 \\
11 / 13 \\
0 / 1\end{array}$ & $\begin{array}{l}<0.002 \\
<0.005 \\
N A\end{array}$ & $\begin{array}{l}<0.005 \\
0.01 \\
<0.005\end{array}$ & $\begin{array}{l}0.007 \\
0.08 \\
\text { NA }\end{array}$ \\
\hline \multicolumn{6}{|l|}{ Silica ${ }^{\circ}$} \\
\hline $\begin{array}{l}\text { Background } \\
\text { On-site } \\
\text { Spring }\end{array}$ & $\begin{array}{l}632 \\
538\end{array}$ & $\begin{array}{l}4 / 4 \\
2 / 2 \\
0 / 0\end{array}$ & $\begin{array}{l}12 \\
20 \\
N A\end{array}$ & $\begin{array}{l}12 \\
22 \\
\text { NA }\end{array}$ & $\begin{array}{l}13 \\
24 \\
\text { NA }\end{array}$ \\
\hline \multicolumn{6}{|l|}{ Silver ${ }^{\circ}$} \\
\hline $\begin{array}{l}\text { Background } \\
\text { On-site } \\
\text { Spring }\end{array}$ & 538 & $\begin{array}{c}0 / 14 \\
4 / 13 \\
0 / 0\end{array}$ & $\begin{array}{l}<0.01 \\
<0.01 \\
\text { NA }\end{array}$ & $\begin{array}{l}<0.01 \\
<0.01 \\
\text { NA }\end{array}$ & $\begin{array}{l}<0.01 \\
0.03 \\
\text { NA }\end{array}$ \\
\hline \multicolumn{6}{|l|}{ Sodium ${ }^{e}$} \\
\hline $\begin{array}{l}\text { Background } \\
\text { On-site } \\
\text { Spring }\end{array}$ & $\begin{array}{l}616 \\
538\end{array}$ & $\begin{array}{l}15 / 15 \\
6 / 6 \\
0 / 0\end{array}$ & $\begin{array}{l}35 \\
801 \\
\text { NA }\end{array}$ & $\begin{array}{l}48 \\
997 \\
\text { NA }\end{array}$ & $\begin{array}{l}66 \\
1080 \\
N A\end{array}$ \\
\hline \multicolumn{6}{|l|}{ Strontium } \\
\hline $\begin{array}{l}\text { Background } \\
\text { On-site } \\
\text { Spring }\end{array}$ & $\begin{array}{l}656 \\
538\end{array}$ & $\begin{array}{l}15 / 15 \\
6 / 6 \\
1 / 1\end{array}$ & $\begin{array}{l}0.82 \\
4.1 \\
\text { NA }\end{array}$ & $\begin{array}{l}1.2 \\
5.5 \\
1.6\end{array}$ & $\begin{array}{l}2.0 \\
7.2 \\
\text { NA }\end{array}$ \\
\hline \multicolumn{6}{|l|}{ Sulfate $^{\theta}$} \\
\hline $\begin{array}{l}\text { Background } \\
\text { On-site } \\
\text { Spring }\end{array}$ & $\begin{array}{l}616 \\
538 \\
\end{array}$ & $\begin{array}{c}15 / 15 \\
6 / 6 \\
1 / 1 \\
\end{array}$ & $\begin{array}{l}244 \\
1030 \\
N A \\
\end{array}$ & $\begin{array}{l}348 \\
1200 \\
391 \\
\end{array}$ & $\begin{array}{l}605 \\
1450 \\
\mathrm{NA} \\
\end{array}$ \\
\hline
\end{tabular}


Table 2.1 Comparison of background and on-site ground water quality in the alluvial aquifer and downgradient spring water quality, Naturita, Colorado, site (Continued)

\begin{tabular}{|c|c|c|c|c|c|}
\hline Constituent & Well IDa & $\begin{array}{l}\text { Frequency } \\
\text { of detection }^{\text {b }}\end{array}$ & $\begin{array}{c}\text { Minimum } \\
(\mathrm{mg} / \mathrm{L})\end{array}$ & $\begin{array}{l}\text { Median }^{c} \\
\text { (mg/L) }\end{array}$ & $\begin{array}{c}\text { Maximum } \\
\text { (mg/L) }\end{array}$ \\
\hline \multicolumn{6}{|l|}{ Sulfide } \\
\hline Background & & $3 / 14$ & $<0.1$ & $<0.1$ & 2.3 \\
\hline On-site & & $3 / 13$ & $<0.1$ & $<0.1$ & 2.3 \\
\hline Spring & 538 & $0 / 0$ & NA & NA & NA \\
\hline \multicolumn{6}{|l|}{ Thallium } \\
\hline Background & & $0 / 10$ & $<0.01$ & $<0.01$ & $<0.1$ \\
\hline On-site & & $0 / 9$ & $<0.01$ & $<0.01$ & $<0.1$ \\
\hline Spring & 538 & $0 / 0$ & NA & NA & NA \\
\hline \multicolumn{6}{|l|}{ Tin } \\
\hline Background & & $0 / 14$ & $<0.005$ & $<0.005$ & $<0.01$ \\
\hline On-site & & $2 / 11$ & $<0.005$ & $<0.01$ & 0.13 \\
\hline Spring & 538 & $0 / 0$ & NA & NA & NA \\
\hline \multicolumn{6}{|l|}{ Uranium $^{\bullet}$} \\
\hline Background & & $15 / 15$ & 0.002 & 0.012 & 0.025 \\
\hline On-site & & $13 / 13$ & 1.0 & 2.2 & 5.2 \\
\hline Spring & 538 & $1 / 1$ & NA & 0.11 & NA \\
\hline \multicolumn{6}{|l|}{ Vanadium $^{\ominus}$} \\
\hline Background & & $6 / 15$ & $<0.01$ & $<0.01$ & 0.02 \\
\hline On-site & 616 & $6 / 6$ & 1.5 & 6.4 & 10 \\
\hline Spring & 538 & $0 / 1$ & NA & $<0.01$ & NA \\
\hline \multicolumn{6}{|l|}{ Zinc } \\
\hline Background & & $15 / 15$ & 0.018 & 0.057 & 0.08 \\
\hline On-site & & $5 / 13$ & $<0.005$ & $<0.005$ & 0.11 \\
\hline Spring & 538 & $0 / 1$ & NA & $<0.05$ & NA. \\
\hline
\end{tabular}


Table 2.1 Comparison of background and on-site ground water quality in the alluvial aquifer and downgradient spring water quality, Naturita, Colorado, site (Concluded)

\begin{tabular}{|c|c|c|c|c|c|}
\hline Constituent & Well ID & $\begin{array}{l}\text { Frequency } \\
\text { of detection }^{b}\end{array}$ & $\begin{array}{c}\text { Minimum } \\
(\mathrm{pCi} / \mathrm{L})\end{array}$ & $\begin{array}{c}\text { Medianc } \\
\text { (pCi/L) }\end{array}$ & $\begin{array}{l}\text { Maximum } \\
(\mathrm{pCi} / \mathrm{L})\end{array}$ \\
\hline $\begin{array}{l}\text { Radionuclides } \\
\text { Lead-210 }\end{array}$ & & & & & \\
\hline $\begin{array}{l}\text { Background } \\
\text { On-site } \\
\text { Spring }\end{array}$ & 538 & $\begin{array}{l}4 \\
4 \\
0\end{array}$ & $\begin{array}{l}0.0 \\
3.4 \\
\text { NA }\end{array}$ & $\begin{array}{l}0.3 \\
5.2 \\
\text { NA }\end{array}$ & $\begin{array}{l}0.6 \\
13.5 \\
N A\end{array}$ \\
\hline Polonium-210 ${ }^{\circ}$ & & & & & \\
\hline $\begin{array}{l}\text { Background } \\
\text { On-site } \\
\text { Spring }\end{array}$ & 538 & $\begin{array}{l}4 \\
4 \\
0\end{array}$ & $\begin{array}{l}0.0 \\
0.5 \\
\text { NA }\end{array}$ & $\begin{array}{l}0.1 \\
0.9 \\
\text { NA }\end{array}$ & $\begin{array}{l}0.2 \\
4.5 \\
\text { NA }\end{array}$ \\
\hline Radium-226 & & & & & \\
\hline $\begin{array}{l}\text { Background } \\
\text { On-site } \\
\text { Soring }\end{array}$ & 538 & $\begin{array}{c}15 \\
13 \\
0\end{array}$ & $\begin{array}{l}0.0 \\
3.2 \\
\text { NA }\end{array}$ & $\begin{array}{l}0.1 \\
4.9 \\
\text { NA }\end{array}$ & $\begin{array}{l}0.6 \\
28.6 \\
N A\end{array}$ \\
\hline Radium-228 ${ }^{\circ}$ & & & & & \\
\hline $\begin{array}{l}\text { Background } \\
\text { On-site } \\
\text { Spring }\end{array}$ & 538 & $\begin{array}{c}15 \\
13 \\
0\end{array}$ & $\begin{array}{l}0.0 \\
0.0 \\
\text { NA }\end{array}$ & $\begin{array}{l}0.2 \\
1.1 \\
\text { NA }\end{array}$ & $\begin{array}{l}6.7 \\
3.4 \\
\text { NA }\end{array}$ \\
\hline $\begin{array}{c}\text { Thorium-230 } \\
\text { Background } \\
\text { On-site } \\
\text { Spring }\end{array}$ & 538 & $\begin{array}{l}4 \\
4 \\
0\end{array}$ & $\begin{array}{l}0.0 \\
0.0 \\
\text { NA }\end{array}$ & $\begin{array}{l}0.1 \\
0.6 \\
\text { NA }\end{array}$ & $\begin{array}{l}0.3 \\
0.9 \\
\text { NA }\end{array}$ \\
\hline
\end{tabular}

${ }^{8}$ Background data are from 547 and 549; on-site data are from combined monitor wells 616 and 632 , unless otherwise specified.

${ }^{b}$ Frequency of detection = number of samples reported at or above the detection limit/total number of samples

'Median $=$ the 50th percentile of the data.

${ }^{D}$ Certain nondetect data associated with matrix interferences were omitted.

${ }^{\circ}$ Constituent is above background.

'The spring was sampled only one time in November 1994.

NA - not available.

Note: July 1989 - April 1994 filtered water samples were used. 


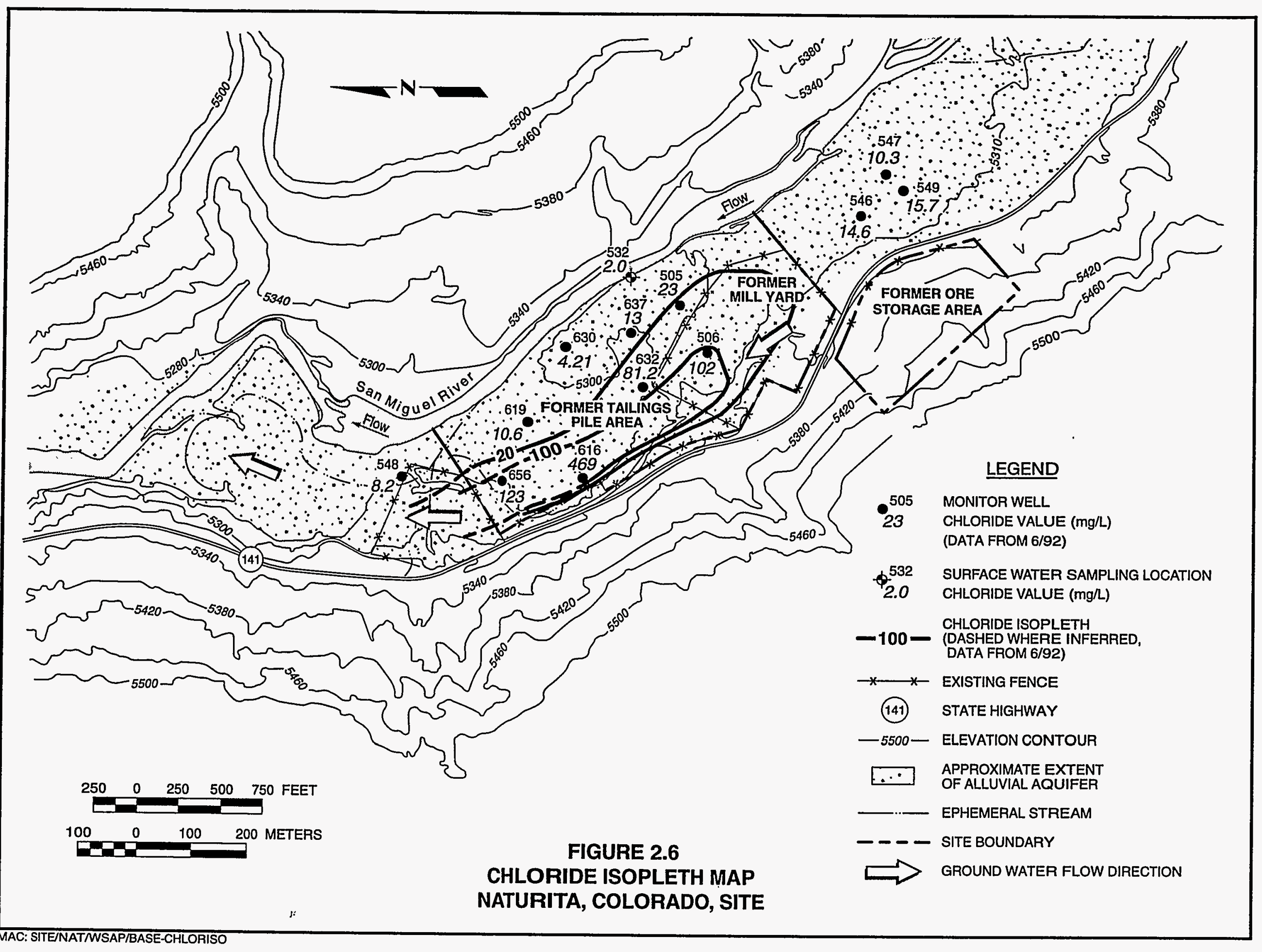


In contrast, uranium concentrations that exceed background are distributed over a much larger area (Figure 2.7). This distribution is the result of multiple sources of uranium. Alkaline leach tails had a higher concentration of uranium than acid leach tails deposited on the eastern half of the site. This source of contamination has been removed. However, tailings used as fill material are still present in the lower terrace of the former mill site (DOE, 1995a) and are likely contributing uranium to the ground water on the eastern half of the site.

At the Naturita site, the alluvium is laterally truncated to the west by an escarpment of Morrison Formation (Figures 2.6 and 2.7). Therefore, contamination and ground water flow in the alluvium is effectively limited to the area between the escarpment of Morrison Formation west of the site and the San Miguel River east of the site with ground water flowing north, parallel to the river. Consequently, contamination is distributed in an elongate pattem to the north from the site, in the direction of ground water flow (Figures 2.6 and 2.7).

A downgradient spring representing a ground water discharge point (location 538) was sampled in November 1994, and the resulting concentration of uranium was $0.11 \mathrm{mg} / \mathrm{L}$. Additional sampling of this location is required to verify this result. Pending verification of water quality conditions at this location, uranium concentrations at this location may represent the known downgradient extent of ground water contamination.

An estimate of the vertical extent of contamination is given in a hydrogeologic cross section that extends from background well 547 to the San Miguel River near spring location 538 (Figure 2.8). The distribution of uranium in this figure shows the highest uranium concentrations in the shallower, clay-rich alluvium and lower concentrations in the deeper portion of the aquifer, near the interface between the alluvium and the Brushy Basin Member of the Morrison Formation. This configuration is the result of a layer of coarse gravel and cobbles observed at the base of the alluvium. Ground water moves much more quickly through the gravel and cobbles than it does through the clay-rich upper alluvium. Thus, contamination moving down from near the surface may be diluted when it reaches the gravel and cobble layer near the bottom of the alluvium.

\subsubsection{Surface water sampling locations}

The Naturita uranium processing site is adjacent to the San Miguel River and the hydrologic gradients indicate that the alluvial aquifer discharges into the river. Analyses of surface water from three locations along the San Miguel River are available from 1986 through 1994 (Figure 1.4). These include one upstream location, one location adjacent to the site, and one downstream location.

Additionally, two rounds of surface water sampling and one round of sediment sampling were completed in 1994 to support the risk assessment that included one additional up stream and two additional down stream locations (Figure 1.4). The November 1994 sampling period was chosen to coincide with the onset of seasonal low flow in the river since the potential impact of contaminant discharge would be greatest during the low flow period. The results of all surface water sampling and analyses conducted between 1986 and 1994 are summarized in Table 2.2. 


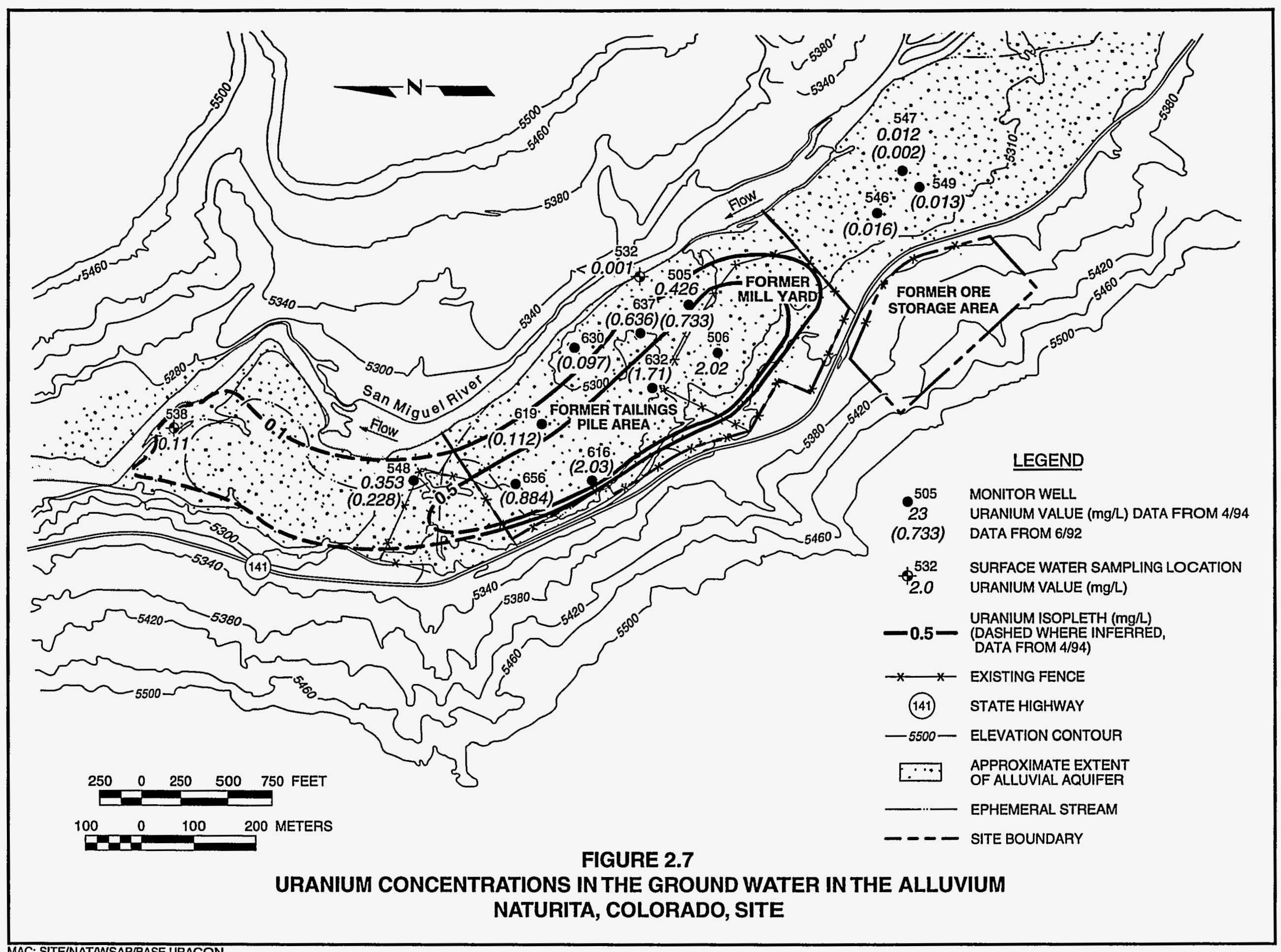




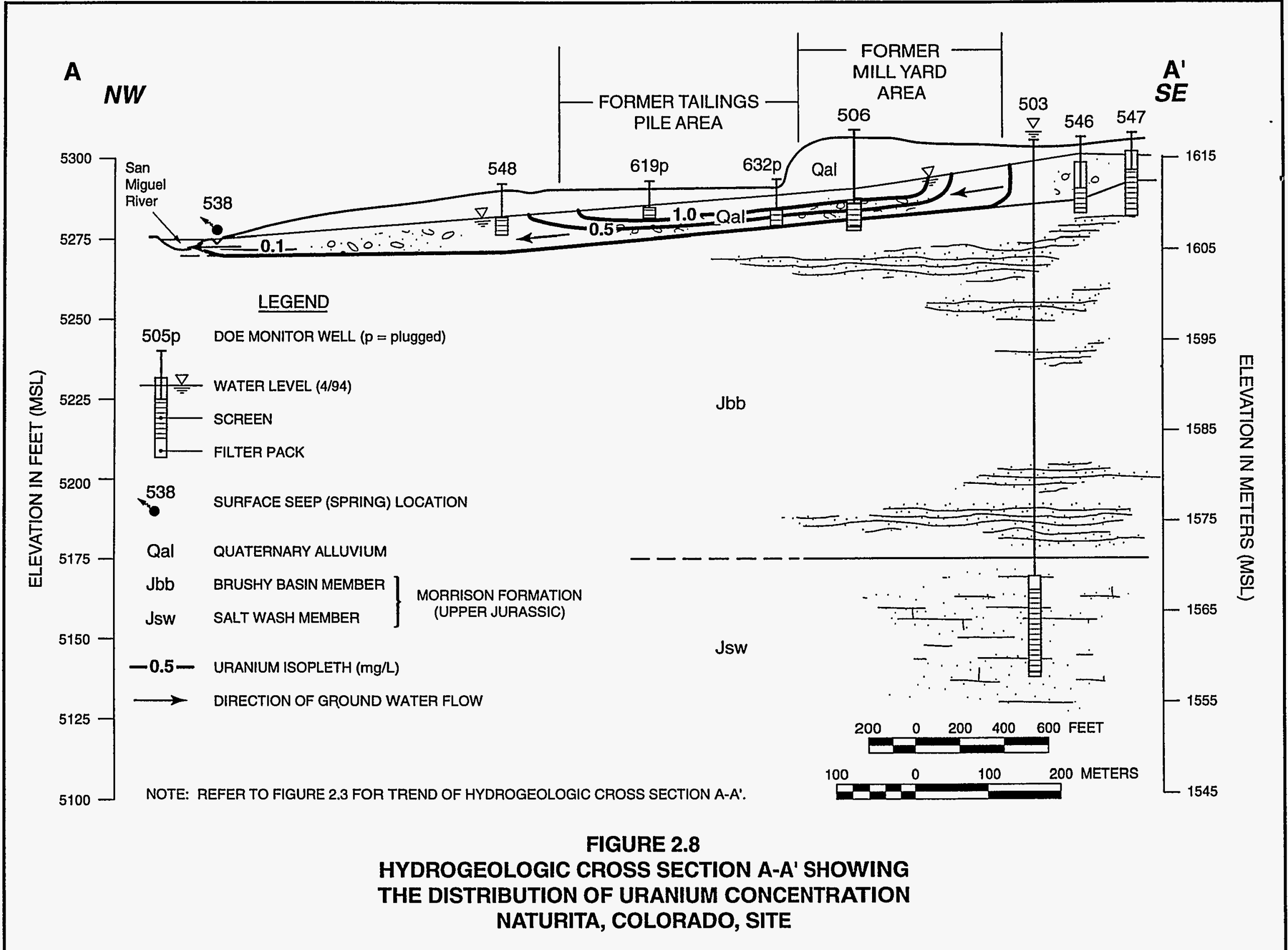


Water quality of the San Miguel River in the vicinity of the Naturita site is dominated by calcium and sulfate, with TDS concentrations fluctuating from near $200 \mathrm{mg} / \mathrm{L}$ up to $800 \mathrm{mg} / \mathrm{L}$ depending on the time of year. Statistical evaluation of 12 rounds of data from filtered and unfiltered water samples at surface locations 531,532 , and 533 identified no statistically significant elevation in downstream concentrations of the major cations, anions, or trace metals, including uranium. However, radium-226 concentrations in water samples from surface location 532, immediately adjacent to the former tailings pile area, were statistically higher than samples from the upstream location 531. The actual difference between the two locations is small with medians of 0.0 and $0.1 \mathrm{pCi} / \mathrm{L}$ from locations 531 and 532, respectively.

The possible presence of additional radionuclides (thorium-230, polonium-210, and lead-210) in the river water adjacent to the site could not be assessed statistically at the present time because fewer data are available for these constituents.

\subsection{SITE CONCEPTUAL MODEL}

The tailings pile was removed from the site and relocated to Coke Oven, Colorado. Although there are still about $250,000 \mathrm{yd}^{3}\left(190,000 \mathrm{~m}^{3}\right)$ of contaminated soils at the site these contaminated soils and materials are being removed. They will be relocated to a disposal cell at Uravan, Colorado, before the site is released for any future use. Also, access to the contaminated area has been restricted until the surface clean-up is completed.

The primary sources of contamination remaining at the Naturita processing site include sub-tailings soil and contaminated soil in the former mill yard. The latter contains tailings used as fill material on the lower mill terrace. The sub-tailings soil contains contaminants that were leached out of the tailings by acidic pore fluids and were subsequently precipitated or adsorbed when acidic solutions were neutralized by naturally occurring carbonate minerals in soils beneath the pile.

There are a large number of factors affecting contaminant distribution at the Naturita site. For example, the limited extent of the alluvium at the site limits the extent of contamination and the composition of the alluvium, ranging from clay-rich to dominantly coarse gravel and cobbles, and affects contaminant concentrations. Waste disposal practices at the site (i.e., location of the alkaline and acid leach tailings) also influence contaminant distribution. Additionally, contaminants in ground water move at different rates due to difference in degree of participation in precipitation and adsorption reactions. Thus, contaminant distribution at the site is not uniform from one constituent to another. It is possible, however, to say that the area with the highest levels of contamination is approximated by the $20 \mathrm{mg} / \mathrm{L}$ chloride isopleth in Figure 2.6, and the maximum extent of contamination is likely approximated by the $0.1 \mathrm{mg} / \mathrm{L}$ uranium isopleth of Figure 2.7 . 
Table 2.2 Comparison of upstream and downstream water quality data for constituents above background in ground water, San Miguel River, Naturita, Colorado, site

\begin{tabular}{|c|c|c|c|c|c|c|}
\hline \multirow[b]{2}{*}{ Constituent } & \multirow[b]{2}{*}{$\begin{array}{c}\text { Location } \\
\text { ID }\end{array}$} & \multicolumn{4}{|c|}{ Filtered samples } & \multirow{2}{*}{$\begin{array}{c}\begin{array}{c}\text { Unfiltered } \\
\text { samples }\end{array} \\
\text { Maximum } \\
\end{array}$} \\
\hline & & $\begin{array}{c}\text { Frequency of } \\
\text { detection }\end{array}$ & Minimum & Median $^{c}$ & Maximum & \\
\hline \multicolumn{7}{|l|}{ Aluminum } \\
\hline $\begin{array}{l}\text { Upstream } \\
\text { Downstream } \\
\text { Downstream }\end{array}$ & $\begin{array}{l}531 \\
532 \\
533\end{array}$ & $\begin{array}{l}3 / 8 \\
3 / 8 \\
3 / 8\end{array}$ & $\begin{array}{l}<0.05 \\
<0.05 \\
<0.05\end{array}$ & $\begin{array}{l}<0.10 \\
<0.10 \\
<0.10\end{array}$ & $\begin{array}{l}0.50 \\
0.30 \\
0.50\end{array}$ & $\begin{array}{l}2.35 \\
2.10 \\
2.20\end{array}$ \\
\hline \multicolumn{7}{|l|}{ Antimony } \\
\hline $\begin{array}{l}\text { Upstream } \\
\text { Downstream } \\
\text { Downstream } \\
\text { Upstream } \\
\text { Downstream } \\
\text { Downstream }\end{array}$ & $\begin{array}{l}531 \\
532 \\
533 \\
534 \\
535 \\
536\end{array}$ & $\begin{array}{l}2 / 8 \\
0 / 9 \\
1 / 8 \\
0 / 2 \\
1 / 2 \\
0 / 2\end{array}$ & $\begin{array}{l}<0.003 \\
<0.003 \\
<0.003 \\
<0.003 \\
<0.003 \\
<0.003\end{array}$ & $\begin{array}{l}<0.003 \\
<0.003 \\
<0.003 \\
<0.003 \\
<0.003 \\
<0.003\end{array}$ & $\begin{array}{r}0.007 \\
<0.003 \\
0.003 \\
<0.003 \\
0.003 \\
<0.003\end{array}$ & $\begin{array}{l}0.005 \\
<0.003 \\
<0.003 \\
\text { NA } \\
\text { NA } \\
\text { NA }\end{array}$ \\
\hline $\begin{array}{l}\text { Arsenic } \\
\text { Upstream } \\
\text { Downstream } \\
\text { Downstream } \\
\text { Upstream } \\
\text { Downstream } \\
\text { Downstream }\end{array}$ & $\begin{array}{l}531 \\
532 \\
533 \\
534 \\
535 \\
536\end{array}$ & $\begin{array}{l}2 / 11 \\
1 / 11 \\
2 / 11 \\
0 / 2 \\
0 / 2 \\
0 / 2\end{array}$ & $\begin{array}{r}0.002 \\
<0.001 \\
0.001 \\
<0.005 \\
<0.005 \\
<0.005\end{array}$ & $\begin{array}{l}<0.01 \\
<0.01 \\
<0.01 \\
<0.005 \\
<0.005 \\
<0.005\end{array}$ & $\begin{array}{l}<0.01 \\
<0.01 \\
<0.01 \\
<0.005 \\
<0.005 \\
<0.005\end{array}$ & $\begin{array}{l}<0.01 \\
<0.01 \\
<0.01 \\
0.005 \\
0.005 \\
0.005\end{array}$ \\
\hline $\begin{array}{l}\text { Barium } \\
\text { Upstream } \\
\text { Downstream } \\
\text { Downstream }\end{array}$ & $\begin{array}{l}531 \\
532 \\
533\end{array}$ & $\begin{array}{l}3 / 7 \\
4 / 8 \\
3 / 7\end{array}$ & $\begin{array}{l}0.05 \\
0.05 \\
0.05\end{array}$ & $\begin{array}{l}<0.10 \\
<0.10 \\
<0.10\end{array}$ & $\begin{array}{r}<0.10 \\
0.30 \\
<0.10\end{array}$ & $\begin{array}{l}0.11 \\
0.10 \\
0.24\end{array}$ \\
\hline $\begin{array}{l}\text { Boron } \\
\text { Upstream } \\
\text { Downstream } \\
\text { Downstream }\end{array}$ & $\begin{array}{l}531 \\
532 \\
533\end{array}$ & $\begin{array}{l}1 / 3 \\
1 / 4 \\
1 / 3\end{array}$ & $\begin{array}{l}<0.10 \\
<0.10 \\
<0.10\end{array}$ & $\begin{array}{l}<0.10 \\
<0.10 \\
<0.10\end{array}$ & $\begin{array}{l}0.13 \\
0.10 \\
0.11\end{array}$ & $\begin{array}{l}<0.10 \\
<0.10 \\
<0.10\end{array}$ \\
\hline \multicolumn{7}{|l|}{ Calcium } \\
\hline $\begin{array}{l}\text { Upstream } \\
\text { Downstream } \\
\text { Downstream } \\
\text { Upstream } \\
\text { Downstream } \\
\text { Downstream }\end{array}$ & $\begin{array}{l}531 \\
532 \\
533 \\
534 \\
535 \\
536\end{array}$ & $\begin{array}{l}11 / 11 \\
11 / 11 \\
11 / 11 \\
2 / 2 \\
2 / 2 \\
2 / 2\end{array}$ & $\begin{array}{l}41 \\
41 \\
29 \\
40.6 \\
40.0 \\
40.0\end{array}$ & $\begin{array}{l}80 \\
79 \\
79 \\
64.8 \\
66.8 \\
65.1\end{array}$ & $\begin{array}{l}121 \\
107 \\
115 \\
88.9 \\
93.6 \\
90.1\end{array}$ & $\begin{array}{l}96 \\
86 \\
87 \\
\text { NA } \\
\text { NA } \\
\text { NA }\end{array}$ \\
\hline
\end{tabular}


Table 2.2 Comparison of upstream and downstream water quality data for constituents above background in ground water, San Miguel River, Naturita, Colorado, site (Continued)

\begin{tabular}{|c|c|c|c|c|c|c|}
\hline \multirow[b]{2}{*}{ Constituent } & \multirow[b]{2}{*}{$\begin{array}{l}\text { Location } \\
\text { ID }\end{array}$} & \multicolumn{4}{|c|}{ Filtered samples } & \multirow{2}{*}{$\begin{array}{l}\begin{array}{c}\text { Unfiltered } \\
\text { samples }\end{array} \\
\text { Maximum }\end{array}$} \\
\hline & & $\begin{array}{l}\text { Frequency of } \\
\text { detection }\end{array}$ & Minimum & Median ${ }^{c}$ & Maximum & \\
\hline \multicolumn{7}{|l|}{ Chloride } \\
\hline $\begin{array}{l}\text { Upstream } \\
\text { Downstream } \\
\text { Downstream } \\
\text { Upstream } \\
\text { Downstream } \\
\text { Downstream }\end{array}$ & $\begin{array}{l}531 \\
532 \\
533 \\
534 \\
535 \\
536\end{array}$ & $\begin{array}{l}11 / 11 \\
11 / 11 \\
11 / 11 \\
2 / 2 \\
2 / 2 \\
2 / 2\end{array}$ & $\begin{array}{l}1.7 \\
1.0 \\
1.8 \\
2.2 \\
1.9 \\
2.0\end{array}$ & $\begin{array}{l}4.4 \\
4.1 \\
3.7 \\
3.1 \\
2.9 \\
2.8\end{array}$ & $\begin{array}{c}15 \\
14 \\
13 \\
4.0 \\
3.8 \\
3.6\end{array}$ & $\begin{array}{l}7.0 \\
7.0 \\
6.0 \\
\text { NA } \\
\text { NA } \\
\text { NA }\end{array}$ \\
\hline \multicolumn{7}{|l|}{ Fluoride } \\
\hline $\begin{array}{l}\text { Upstream } \\
\text { Downstream } \\
\text { Downstream }\end{array}$ & $\begin{array}{l}531 \\
532 \\
533\end{array}$ & $\begin{array}{c}8 / 9 \\
9 / 10 \\
8 / 9\end{array}$ & $\begin{array}{l}<0.10 \\
<0.10 \\
<0.10\end{array}$ & $\begin{array}{l}0.30 \\
0.27 \\
0.30\end{array}$ & $\begin{array}{l}0.40 \\
0.40 \\
0.40\end{array}$ & $\begin{array}{l}0.30 \\
0.30 \\
0.30\end{array}$ \\
\hline \multicolumn{7}{|l|}{ Magnesium } \\
\hline $\begin{array}{l}\text { Upstream } \\
\text { Downstream } \\
\text { Downstream } \\
\text { Upstream } \\
\text { Downstream } \\
\text { Downstream }\end{array}$ & $\begin{array}{l}531 \\
532 \\
533 \\
534 \\
535 \\
536\end{array}$ & $\begin{array}{l}11 / 11 \\
11 / 11 \\
11 / 11 \\
2 / 2 \\
2 / 2 \\
2 / 2\end{array}$ & $\begin{array}{l}8.1 \\
8.2 \\
6.2 \\
7.9 \\
8.3 \\
8.0\end{array}$ & $\begin{array}{l}21 \\
17 \\
18 \\
15 \\
16 \\
15\end{array}$ & $\begin{array}{l}53 \\
45 \\
48 \\
23 \\
24 \\
22\end{array}$ & $\begin{array}{l}28 \\
27 \\
25 \\
\text { NA } \\
\text { NA } \\
\text { NA }\end{array}$ \\
\hline \multicolumn{7}{|l|}{ Manganese } \\
\hline $\begin{array}{l}\text { Upstream } \\
\text { Downstream } \\
\text { Downstream } \\
\text { Upstream } \\
\text { Downstream } \\
\text { Downstream }\end{array}$ & $\begin{array}{l}531 \\
532 \\
533 \\
534 \\
535 \\
536\end{array}$ & $\begin{array}{c}11 / 11 \\
11 / 11 \\
11 / 11 \\
1 / 2 \\
2 / 2 \\
2 / 2\end{array}$ & $\begin{array}{r}0.01 \\
0.01 \\
0.01 \\
<0.01 \\
0.01 \\
0.01\end{array}$ & $\begin{array}{r}0.03 \\
0.02 \\
0.02 \\
<0.02 \\
0.02 \\
0.02\end{array}$ & $\begin{array}{l}0.05 \\
0.06 \\
0.10 \\
0.02 \\
0.02 \\
0.02\end{array}$ & $\begin{array}{l}0.15 \\
0.13 \\
0.20 \\
0.13 \\
0.10 \\
0.18\end{array}$ \\
\hline \multicolumn{7}{|l|}{ Molybdenum } \\
\hline $\begin{array}{l}\text { Upstream } \\
\text { Downstream } \\
\text { Downstream } \\
\text { Upstream } \\
\text { Downstream } \\
\text { Downstream } \\
\end{array}$ & $\begin{array}{l}531 \\
532 \\
533 \\
534 \\
535 \\
536 \\
\end{array}$ & $\begin{array}{l}3 / 11 \\
3 / 11 \\
3 / 11 \\
0 / 2 \\
0 / 2 \\
0 / 2 \\
\end{array}$ & $\begin{array}{l}<0.01 \\
<0.01 \\
<0.01 \\
<0.01 \\
<0.01 \\
<0.01\end{array}$ & $\begin{array}{l}<0.01 \\
<0.01 \\
<0.01 \\
<0.01 \\
<0.01 \\
<0.01 \\
\end{array}$ & $\begin{array}{r}0.26 \\
0.27 \\
0.20 \\
<0.01 \\
<0.01 \\
<0.01 \\
\end{array}$ & $\begin{array}{l}<0.01 \\
<0.01 \\
<0.01 \\
<0.01 \\
<0.01 \\
<0.01\end{array}$ \\
\hline
\end{tabular}


Table 2.2 Comparison of upstream and downstream water quality data for constituents above background in ground water, San Miguel River, Naturita, Colorado, site (Continued)

\begin{tabular}{|c|c|c|c|c|c|c|}
\hline \multirow[b]{2}{*}{ Constituent } & \multirow[b]{2}{*}{$\begin{array}{c}\text { Location } \\
\text { Id }^{\mathrm{a}}\end{array}$} & \multicolumn{4}{|c|}{ Filtered samples } & \multirow{2}{*}{$\begin{array}{c}\begin{array}{c}\text { Unfiltered } \\
\text { samples }\end{array} \\
\text { Maximum }\end{array}$} \\
\hline & & $\begin{array}{c}\text { Frequency of } \\
\text { detection }\end{array}$ & Minimum & Median $^{c}$ & Maximum & \\
\hline $\begin{array}{l}\text { Potassium } \\
\text { Upstream } \\
\text { Downstream } \\
\text { Downstream } \\
\text { Upstream } \\
\text { Downstream } \\
\text { Downstream }\end{array}$ & $\begin{array}{l}\mathbf{5 3 1} \\
\mathbf{5 3 2} \\
\mathbf{5 3 3} \\
\mathbf{5 3 4} \\
\mathbf{5 3 5} \\
\mathbf{5 3 6}\end{array}$ & $\begin{array}{l}9 / 10 \\
9 / 10 \\
9 / 10 \\
1 / 1 \\
1 / 1 \\
1 / 1\end{array}$ & $\begin{array}{l}1.2 \\
1.2 \\
1.3 \\
\text { NA } \\
\text { NA } \\
\text { NA }\end{array}$ & $\begin{array}{l}1.7 \\
1.7 \\
1.9 \\
1.7 \\
1.7 \\
1.7\end{array}$ & $\begin{array}{l}3.2 \\
2.9 \\
3.1 \\
\text { NA } \\
\text { NA } \\
\text { NA }\end{array}$ & $\begin{array}{l}3.1 \\
3.1 \\
2.8 \\
\text { NA } \\
\text { NA } \\
\text { NA }\end{array}$ \\
\hline $\begin{array}{l}\text { Selenium } \\
\text { Upstream } \\
\text { Downstream } \\
\text { Downstream } \\
\text { Upstream } \\
\text { Downstream } \\
\text { Downstream }\end{array}$ & $\begin{array}{l}531 \\
532 \\
533 \\
534 \\
535 \\
536\end{array}$ & $\begin{array}{l}1 / 10 \\
1 / 11 \\
1 / 11 \\
0 / 2 \\
0 / 2 \\
0 / 2\end{array}$ & $\begin{array}{l}<0.002 \\
<0.002 \\
<0.002 \\
<0.005 \\
<0.005 \\
<0.005\end{array}$ & $\begin{array}{l}<0.005 \\
<0.005 \\
<0.005 \\
<0.005 \\
<0.005 \\
<0.005\end{array}$ & $\begin{array}{r}0.004 \\
0.002 \\
0.003 \\
<0.005 \\
<0.005 \\
<0.005\end{array}$ & $\begin{array}{l}<0.005 \\
<0.005 \\
<0.005 \\
<0.005 \\
<0.005 \\
<0.005\end{array}$ \\
\hline $\begin{array}{l}\text { Silica } \\
\text { Upstream } \\
\text { Downstream } \\
\text { Downstream }\end{array}$ & $\begin{array}{l}531 \\
532 \\
533\end{array}$ & $\begin{array}{l}3 / 3 \\
4 / 4 \\
3 / 3\end{array}$ & $\begin{array}{l}7.7 \\
3.0 \\
7.7\end{array}$ & $\begin{array}{l}8.0 \\
7.7 \\
8.0\end{array}$ & $\begin{array}{l}8.3 \\
8.5 \\
8.5\end{array}$ & $\begin{array}{r}8.0 \\
10.0 \\
8.0\end{array}$ \\
\hline $\begin{array}{l}\text { Silver } \\
\text { Upstream } \\
\text { Downstream } \\
\text { Downstream }\end{array}$ & $\begin{array}{l}531 \\
532 \\
533\end{array}$ & $\begin{array}{l}1 / 7 \\
1 / 8 \\
1 / 7\end{array}$ & $\begin{array}{l}<0.01 \\
<0.01 \\
<0.01\end{array}$ & $\begin{array}{l}<0.01 \\
<0.01 \\
<0.01\end{array}$ & $\begin{array}{l}0.020 \\
0.014 \\
0.013\end{array}$ & $\begin{array}{l}<0.01 \\
<0.01 \\
<0.01\end{array}$ \\
\hline $\begin{array}{l}\text { Sodium } \\
\text { Upstream } \\
\text { Downstream } \\
\text { Downstream } \\
\text { Upstream } \\
\text { Downstream } \\
\text { Downstream }\end{array}$ & $\begin{array}{l}531 \\
532 \\
533 \\
534 \\
535 \\
536\end{array}$ & $\begin{array}{c}10 / 10 \\
10 / 10 \\
10 / 10 \\
1 / 1 \\
1 / 1 \\
1 / 1\end{array}$ & $\begin{array}{c}7.0 \\
7.0 \\
7.0 \\
\text { NA } \\
\text { NA } \\
\text { NA }\end{array}$ & $\begin{array}{r}21 \\
21 \\
22 \\
6 \\
7 \\
7\end{array}$ & $\begin{array}{r}100 \\
42 \\
100 \\
\text { NA } \\
\text { NA } \\
\text { NA }\end{array}$ & $\begin{array}{l}30 \\
29 \\
28 \\
\text { NA } \\
\text { NA } \\
\text { NA }\end{array}$ \\
\hline $\begin{array}{l}\text { Strontium } \\
\text { Upstream } \\
\text { Downstream } \\
\text { Downstream } \\
\text { Upstream } \\
\text { Downstream } \\
\text { Downstream }\end{array}$ & $\begin{array}{l}531 \\
532 \\
533 \\
534 \\
535 \\
536\end{array}$ & $\begin{array}{l}8 / 8 \\
8 / 8 \\
8 / 8 \\
2 / 2 \\
2 / 2 \\
2 / 2 \\
\end{array}$ & $\begin{array}{l}0.37 \\
0.35 \\
0.34 \\
0.34 \\
0.35 \\
0.34\end{array}$ & $\begin{array}{l}0.90 \\
0.93 \\
0.93 \\
1.45 \\
0.77 \\
0.77 \\
\end{array}$ & $\begin{array}{l}1.2 \\
1.2 \\
1.2 \\
1.11 \\
1.19 \\
1.10 \\
\end{array}$ & $\begin{array}{l}1.1 \\
1.1 \\
1.1 \\
0.36 \\
0.36 \\
0.38 \\
\end{array}$ \\
\hline
\end{tabular}


Table 2.2 Comparison of upstream and downstream water quality data for constituents above background in ground water, San Miguel River, Naturita, Colorado, site (Continued)

\begin{tabular}{|c|c|c|c|c|c|c|}
\hline \multirow[b]{2}{*}{ Constituent } & \multirow[b]{2}{*}{$\begin{array}{c}\text { Location } \\
1 D^{2}\end{array}$} & \multicolumn{4}{|c|}{ Filtered samples } & \multirow{2}{*}{$\begin{array}{c}\text { Unfiltered } \\
\text { samples } \\
\text { Maximum }\end{array}$} \\
\hline & & $\begin{array}{c}\text { Frequency of } \\
\text { detection }\end{array}$ & Minimum & Median $^{c}$ & Maximum & \\
\hline \multicolumn{7}{|l|}{ Sulfate } \\
\hline $\begin{array}{l}\text { Upstream } \\
\text { Downstream } \\
\text { Downstream } \\
\text { Upstream } \\
\text { Downstream } \\
\text { Downstream }\end{array}$ & $\begin{array}{l}531 \\
532 \\
533 \\
534 \\
535 \\
536\end{array}$ & $\begin{array}{c}11 / 11 \\
11 / 11 \\
11 / 11 \\
2 / 2 \\
2 / 2 \\
2 / 2\end{array}$ & $\begin{array}{l}60 \\
59 \\
56 \\
56 \\
55 \\
60\end{array}$ & $\begin{array}{r}193 \\
146 \\
178 \\
38 \\
132 \\
125\end{array}$ & $\begin{array}{l}380 \\
319 \\
337 \\
193 \\
208 \\
190\end{array}$ & $\begin{array}{l}255 \\
253 \\
242 \\
\text { NA } \\
\text { NA } \\
\text { NA }\end{array}$ \\
\hline \multicolumn{7}{|l|}{ Uranium } \\
\hline $\begin{array}{l}\text { Upstream } \\
\text { Downstream } \\
\text { Downstream } \\
\text { Upstream } \\
\text { Downstream } \\
\text { Downstream }\end{array}$ & $\begin{array}{l}531 \\
532 \\
533 \\
534 \\
535 \\
536\end{array}$ & $\begin{array}{l}9 / 11 \\
9 / 11 \\
9 / 11 \\
1 / 2 \\
1 / 2 \\
1 / 2\end{array}$ & $\begin{array}{l}<0.001 \\
<0.001 \\
<0.001 \\
<0.001 \\
<0.001 \\
<0.001\end{array}$ & $\begin{array}{r}0.002 \\
0.002 \\
0.001 \\
<0.002 \\
<0.002 \\
<0.001\end{array}$ & $\begin{array}{l}0.017 \\
0.006 \\
0.003 \\
0.002 \\
0.002 \\
0.001\end{array}$ & $\begin{array}{r}0.003 \\
0.002 \\
0.003 \\
<0.001 \\
<0.001 \\
<0.001\end{array}$ \\
\hline \multicolumn{7}{|l|}{ Vanadium } \\
\hline $\begin{array}{l}\text { Upstream } \\
\text { Downstream } \\
\text { Downstream } \\
\text { Upstream } \\
\text { Downstream } \\
\text { Downstream }\end{array}$ & $\begin{array}{l}531 \\
532 \\
533 \\
534 \\
535 \\
536 \\
\end{array}$ & $\begin{array}{l}5 / 10 \\
5 / 10 \\
5 / 10 \\
0 / 2 \\
0 / 2 \\
0 / 2\end{array}$ & $\begin{array}{l}<0.01 \\
<0.01 \\
<0.01 \\
<0.01 \\
<0.01 \\
<0.01\end{array}$ & $\begin{array}{l}<0.02 \\
<0.01 \\
<0.01 \\
<0.01 \\
<0.01 \\
<0.01\end{array}$ & $\begin{array}{r}0.34 \\
0.20 \\
0.42 \\
<0.01 \\
<0.01 \\
<0.01\end{array}$ & $\begin{array}{l}<0.01 \\
<0.01 \\
<0.01 \\
<0.01 \\
<0.01 \\
<0.01\end{array}$ \\
\hline
\end{tabular}


Table 2.2 Comparison of upstream and downstream water quality data for constituents above background in ground water, San Miguel River, Naturita, Colorado, site (Continued)

\begin{tabular}{|c|c|c|c|c|c|c|}
\hline \multirow[b]{2}{*}{ Constituent } & \multirow[b]{2}{*}{$\begin{array}{c}\text { Location } \\
\text { ID' }\end{array}$} & \multicolumn{4}{|c|}{ Filtered samples } & \multirow{2}{*}{$\begin{array}{c}\text { Unfiltered } \\
\text { samples } \\
\text { Maximum }\end{array}$} \\
\hline & & $\begin{array}{l}\text { Frequency of } \\
\text { detection }\end{array}$ & Minimum & Median $^{c}$ & Maximum & \\
\hline \multicolumn{7}{|l|}{$\begin{array}{l}\text { Radionuclides } \\
\text { Lead-210 }^{\text {d }}\end{array}$} \\
\hline $\begin{array}{l}\text { Upstream } \\
\text { Downstream } \\
\text { Downstream } \\
\text { Upstream } \\
\text { Downstream } \\
\text { Downstream }\end{array}$ & $\begin{array}{l}531 \\
532 \\
533 \\
534 \\
535 \\
536\end{array}$ & $\begin{array}{l}2 \\
3 \\
2 \\
1 \\
1 \\
1\end{array}$ & $\begin{array}{l}0.0 \\
0.0 \\
0.0 \\
\text { NA } \\
\text { NA } \\
\text { NA }\end{array}$ & $\begin{array}{l}0.1 \\
0.4 \\
0.0 \\
\text { NA } \\
\text { NA } \\
\text { NA }\end{array}$ & $\begin{array}{l}0.2 \\
1.2 \\
0.0 \\
\text { NA } \\
\text { NA } \\
\text { NA }\end{array}$ & $\begin{array}{l}0.0 \\
0.3 \\
0.4 \\
1.7 \\
2.4 \\
0.3\end{array}$ \\
\hline $\begin{array}{l}\text { Polonium-210 } \\
\text { Upstream } \\
\text { Downstream } \\
\text { Downstream } \\
\text { Upstream } \\
\text { Downstream } \\
\text { Downstream }\end{array}$ & $\begin{array}{l}531 \\
532 \\
533 \\
534 \\
535 \\
536\end{array}$ & $\begin{array}{l}2 \\
3 \\
2 \\
0 \\
0 \\
0\end{array}$ & $\begin{array}{l}0.0 \\
0.0 \\
0.0 \\
\text { NA } \\
\text { NA } \\
\text { NA }\end{array}$ & $\begin{array}{l}0.1 \\
0.0 \\
0.0 \\
\text { NA } \\
\text { NA } \\
\text { NA }\end{array}$ & $\begin{array}{l}0.2 \\
0.0 \\
0.0 \\
\text { NA } \\
\text { NA } \\
\text { NA }\end{array}$ & $\begin{array}{l}0.6 \\
0.0 \\
0.8 \\
0.0 \\
0.0 \\
0.0\end{array}$ \\
\hline Radium-226 ${ }^{d}$ & & & & & & \\
\hline $\begin{array}{l}\text { Upstream } \\
\text { Downstream } \\
\text { Downstream } \\
\text { Upstream } \\
\text { Downstream } \\
\text { Downstream }\end{array}$ & $\begin{array}{l}531 \\
532 \\
533 \\
534 \\
535 \\
536\end{array}$ & $\begin{array}{l}8 \\
9 \\
8 \\
1 \\
1 \\
1\end{array}$ & $\begin{array}{l}0.0 \\
0.0 \\
0.0 \\
\text { NA } \\
\text { NA } \\
\text { NA }\end{array}$ & $\begin{array}{l}0.1 \\
0.1 \\
0.1 \\
0.1 \\
0.1 \\
0.1\end{array}$ & $\begin{array}{l}0.1 \\
0.4 \\
0.6 \\
\text { NA } \\
\text { NA } \\
\text { NA }\end{array}$ & $\begin{array}{l}0.3 \\
0.4 \\
0.2 \\
0.1 \\
0.0 \\
0.5\end{array}$ \\
\hline $\begin{array}{l}\text { Radium-228 }^{\mathrm{d}} \\
\text { Upstream } \\
\text { Downstream } \\
\text { Downstream } \\
\text { Upstream } \\
\text { Downstream } \\
\text { Downstream }\end{array}$ & $\begin{array}{l}531 \\
532 \\
533 \\
534 \\
535 \\
536\end{array}$ & $\begin{array}{l}8 \\
9 \\
8 \\
1 \\
1 \\
1\end{array}$ & $\begin{array}{l}0.0 \\
0.0 \\
0.0 \\
\text { NA } \\
\text { NA } \\
\text { NA }\end{array}$ & $\begin{array}{l}0.0 \\
0.4 \\
0.4 \\
0.0 \\
3.6 \\
0.0\end{array}$ & $\begin{array}{c}1.1 \\
23 \\
0.9 \\
\text { NA } \\
\text { NA } \\
\text { NA }\end{array}$ & $\begin{array}{c}2.8 \\
11.5 \\
3.3 \\
\text { NA } \\
\text { NA } \\
\text { NA }\end{array}$ \\
\hline
\end{tabular}


Table 2.2 Comparison of upstream and downstream water quality data for constituents above background in ground water, San Miguel River, Naturita, Colorado, site (Concluded)

\begin{tabular}{|c|c|c|c|c|c|c|}
\hline \multirow[b]{2}{*}{ Constituent } & \multirow[b]{2}{*}{$\begin{array}{c}\text { Location } \\
1 D^{2}\end{array}$} & \multicolumn{4}{|c|}{ Filtered samples } & \multirow{2}{*}{$\begin{array}{l}\begin{array}{c}\text { Unfiltered } \\
\text { samples }\end{array} \\
\text { Maximum }\end{array}$} \\
\hline & & $\begin{array}{c}\text { Frequency of } \\
\text { detection }\end{array}$ & Minimum & Median $^{c}$ & Maximum & \\
\hline \multicolumn{7}{|l|}{ Thorium-230 } \\
\hline $\begin{array}{l}\text { Upstream } \\
\text { Downstream } \\
\text { Downstream } \\
\text { Upstream } \\
\text { Downstream } \\
\text { Downstream }\end{array}$ & $\begin{array}{l}531 \\
532 \\
533 \\
534 \\
535 \\
536\end{array}$ & $\begin{array}{l}2 \\
3 \\
2 \\
0 \\
0 \\
0\end{array}$ & $\begin{array}{l}0.0 \\
0.1 \\
0.0 \\
\text { NA } \\
\text { NA } \\
\text { NA }\end{array}$ & $\begin{array}{l}0.1 \\
0.1 \\
0.1 \\
\text { NA } \\
\text { NA } \\
\text { NA }\end{array}$ & $\begin{array}{l}0.1 \\
0.5 \\
0.1 \\
\text { NA } \\
\text { NA } \\
\text { NA }\end{array}$ & $\begin{array}{l}0.2 \\
0.3 \\
0.2 \\
0.1 \\
8.6 \\
0.3\end{array}$ \\
\hline
\end{tabular}

a Locations 531, 532, 533 were sampled from January 1986 to November 1994. Locations 534, 535, 536 were sampled in April and November 1994.

'Frequency of detection = number of samples reported at or above the detection limit divided by the total number of samples.

'Median is the 50th percentile of the data. For parameters having only one round of sampling data, the single reported value is listed in the median column. When there is an even number of samples, the median is the average of the two middle data values.

Data is presented in picocuries per liter.

NA - not available.

Note: Values presented in milligrams per liter unless otherwise noted. 


\subsection{DATA COLLECTION OBJECTIVES}

\subsection{REGULATORY REQUIREMENTS}

The general regulatory requirements for sampling at the site are specified in 40 CFR Part 192 and are described in the WSAP guidance document (DOE, 1995b).

\subsection{COMPLIANCE MONITORING}

There is no compliance monitoring at the Naturita site at this time.

\subsection{SITE CHARACTERIZATION}

Sampling of ground water and surface water will be conducted to:

- Evaluate ground water and surface water based on recommendations in the BLRA, and to monitor current site operational activities associated with the surface.

- Assess the contribution of the alluvial aquifer to the river.

- Characterize background water quality and distinguish the contaminants related to site activities from the naturally occurring constituents and concentrations.

\subsection{OTHER CONSIDERATIONS}

Currently, no other water sampling concerns are at the site that have not already been addressed in Sections 3.1 through 3.3. 


\subsection{DATA QUALITY REQUIREMENTS}

\subsection{ANALYTICAL METHODS, HOLDING TIMES, AND DETECTION LIMITS}

The Statement of Work, UMTRA Project TAC General Inorganic and Radiochemical Analyses (DOE, 1995) describes analytical methods, holding times, and detection limits. Attachments 1 and 5 from this document are shown herein as Tables 4.1 and 4.2, which list the analytical methods, holding times, and detection limits approved and used by the UMTRA Project.

\subsection{SAMPLE FILTRATION}

Water samples will be filtered in accordance with the UMTRA Project Albuquerque Operations Manual (JEG, n.d.) SOP 16.2.1, "Sample Collection, Preservation, and Shipment of Water Samples." According to the SOP, analyte bottles filtered with a 0.45 -micron filter at the request of the site hydrologist and/or site geochemist are as follows:

$\mathrm{A}-1, \mathrm{M}-2, \mathrm{~Pb}-210, \mathrm{Po}-210$, radium-226, radium-228, Th-230, and GA/GB.

Filtered analyte bottles to be collected at the Naturita site are A-1, M-2, radium-226, radium-228, and GA/GB.

\subsection{SAMPLE PRESERVATION AND SHIPMENT}

Soil, water, and other environmental samples will be preserved in accordance with the following SOPS (JEG, n.d.):

14.5.1 Procedures for Handling and Shipping of Geotechnical Samples

16.2.10 Packaging, Shipping, and Custody of Environmental Samples

All samples will be shipped through a chain of custody (COC), as described in Section 4.4.

\subsection{CHAIN-OF-CUSTODY PROCEDURES}

COC procedures are covered in two SOPs (JEG, n.d.). SOP 16.2.10, "Packaging, Shipping, and Custody of Environmental Samples," covers COC for water samples and other environmental samples such as biological samples. SOP 14.5.1, "Procedures for Handling and Shipping of Geotechnical Samples," covers $\mathrm{COC}$ for rock and soil samples. These SOPs will be adhered to when collecting and shipping samples covered in this WSAP. The site manager and site hydrologist or geochemist must approve any deviation from these procedures and justify it in a written memorandum. 
Table 4.1 Sampling preservation techniques and holding times

\begin{tabular}{|c|c|c|c|c|}
\hline Bottle ID & Parameter(s) & Volume/container & Preservation & Holding time \\
\hline \multirow[t]{2}{*}{$A-1$} & $\begin{array}{l}\mathrm{Br}, \mathrm{Cl}, \mathrm{F} \\
\mathrm{SO}_{4}, \mathrm{SiO}_{2}\end{array}$ & 1-L plastic & None, $4^{\circ} \mathrm{C}$ & 28 days \\
\hline & TDS & Above & None, $4^{\circ} \mathrm{C}$ & 7 days \\
\hline \multirow[t]{2}{*}{ M-2 } & $\begin{array}{l}\mathrm{Ag}, \mathrm{Al}, \mathrm{As}, \mathrm{B}, \mathrm{Ba} \\
\mathrm{Be}, \mathrm{Ca}, \mathrm{Cd}, \mathrm{Co}, \mathrm{Cr} \text {, } \\
\mathrm{Cu}, \mathrm{Fe}, \mathrm{Mg}, \mathrm{K}, \mathrm{Mn} \text {, } \\
\mathrm{Mo}, \mathrm{Na}, \mathrm{Ni}, \mathrm{Pb}, \mathrm{Sb} \\
\mathrm{Se}, \mathrm{Sn}, \mathrm{Sr}, \mathrm{Tl}, \mathrm{U} \\
\mathrm{V}, \mathrm{Zn}\end{array}$ & 500-mL plastic & $\mathrm{HNO}_{3}, \mathrm{pH}<2$ & 180 days \\
\hline & $\mathrm{Hg}$ & Above & $\mathrm{HNO}_{3}, \mathrm{pH}<2$ & 28 days \\
\hline $\mathrm{N}-1$ & $\begin{array}{l}\mathrm{NH}_{4}, \mathrm{NO}_{3}, \mathrm{TKN} \\
\mathrm{PO}_{4}\end{array}$ & 500-mL plastic & $\begin{array}{l}\mathrm{H}_{2} \mathrm{SO}_{4}, \mathrm{pH}<2 \\
4^{\circ} \mathrm{C}\end{array}$ & 28 days \\
\hline $\mathrm{CN}$ & Total CN & 1-L plastic & $\begin{array}{l}\mathrm{NaOH}, \mathrm{pH}>12 \\
4^{\circ} \mathrm{C}\end{array}$ & 14 days \\
\hline$s$ & Sulfide & $\begin{array}{l}2 \times 500-m L \\
\text { plastic }\end{array}$ & $\begin{array}{l}\mathrm{NaOH}, \mathrm{pH}>9 \\
\mathrm{Zn} \text { Acetate } \\
4^{\circ} \mathrm{C}\end{array}$ & 7 days \\
\hline DOC & DOC & $\begin{array}{l}500-\mathrm{mL} \\
\text { amber glass }\end{array}$ & $\begin{array}{l}\mathrm{H}_{2} \mathrm{SO}_{4}, \mathrm{pH}<2 \\
4^{\circ} \mathrm{C}\end{array}$ & 28 days \\
\hline TOC & TOC & $\begin{array}{l}500-\mathrm{mL} \\
\text { amber glass }\end{array}$ & $\begin{array}{l}\mathrm{H}_{2} \mathrm{SO}_{4}, \mathrm{pH}<2 \\
4^{\circ} \mathrm{C}\end{array}$ & 28 days \\
\hline Ra-226 & $\mathrm{Ra}-226$ & $2 \times 1-L$ plastic & $\mathrm{HNO}_{3}, \mathrm{pH}<2$ & 180 days \\
\hline Ra-228 & Ra-228 & $2 \times 1-L$ plastic & $\mathrm{HNO}_{3}, \mathrm{pH}<2$ & 180 days \\
\hline $\mathrm{Pb}-210$ & $\mathrm{~Pb}-210$ & 1-L plastic & $\mathrm{HNO}_{3}, \mathrm{pH}<2$ & 180 days \\
\hline Po-210 & Po-210 & 1-L plastic & $\mathrm{HNO}_{3}, \mathrm{pH}<2$ & 180 days \\
\hline Th-230 & Th-230 & 1-L plastic & $\mathrm{HNO}_{3}, \mathrm{pH}<2$ & 180 days \\
\hline GA/B & $\begin{array}{l}\text { Gross alpha, } \\
\text { Gross beta, U }\end{array}$ & 500-mL plastic & $\mathrm{HNO}_{3}, \mathrm{pH}<2$ & 180 days \\
\hline
\end{tabular}

${ }^{2}$ Holding time is calculated from the date and time the sample was taken. 
Table 4.1 Sample preservation techniques and holding times (Concluded)

\begin{tabular}{|c|c|}
\hline \multicolumn{2}{|c|}{ Key } \\
\hline $\begin{array}{l}\mathrm{Br} \text { - bromine } \\
\mathrm{Cl} \text { - chloride } \\
\mathrm{F} \text { - fluorine } \\
\mathrm{SO}_{4} \text { - sulfate } \\
\mathrm{SiO}_{2} \text { - silica } \\
\mathrm{TDS}^{-} \text {total dissolved solids } \\
\mathrm{Ag} \text { - silver } \\
\mathrm{Al} \text { - aluminum } \\
\mathrm{As} \text { - arsenic } \\
\mathrm{B} \text { - boron } \\
\mathrm{Ba} \text { - barium } \\
\mathrm{Be} \text { - beryllium } \\
\mathrm{Ca} \text { - calcium } \\
\mathrm{Cd} \text { - cadmium } \\
\mathrm{Co} \text { - cobalt } \\
\mathrm{Cr} \text { - chromium } \\
\mathrm{Cu} \text { - copper } \\
\mathrm{Fe} \text { - iron } \\
\mathrm{Mg} \text { - magnesium } \\
\mathrm{K} \text { - potassium } \\
\mathrm{Mn} \text { - manganese } \\
\mathrm{Mo} \text { - molybdenum } \\
\mathrm{Na} \text { - sodium } \\
\mathrm{Ni} \text { - nickel } \\
\mathrm{Pb} \text { - lead }\end{array}$ & 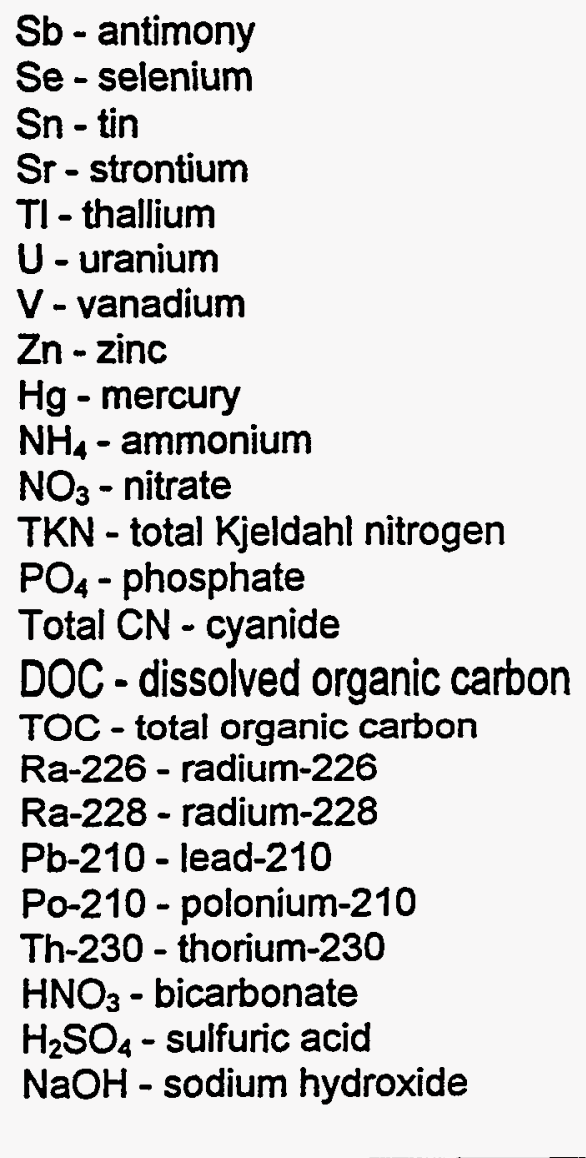 \\
\hline
\end{tabular}


Table 4.2 UMTRA Project detection limits and techniques

\begin{tabular}{|c|c|c|}
\hline Parameter & $\begin{array}{l}\text { Contract-required } \\
\text { detection limit } \\
\text { (mg/L) }\end{array}$ & Technique(s) ${ }^{\mathrm{a}}$ \\
\hline Aluminum & 0.05 & ICP-AES \\
\hline Ammonium as $\mathrm{NH}_{4}$ & 0.10 & Colorimetric \\
\hline Antimony & 0.003 & GFAA, ICP-MS \\
\hline Arsenic & 0.005 & GFAA, $\mathrm{NaBH}_{4}$ \\
\hline Barium & 0.10 & ICP-AES \\
\hline Beryllium & 0.005 & ICP-AES \\
\hline Boron & 0.10 & ICP-AES \\
\hline Bromide & 0.10 & IC \\
\hline Cadmium & 0.001 & GFAA, ICP-MS \\
\hline Calcium & 0.50 & CP-AES \\
\hline Chloride & 0.50 & IC, colorimetric \\
\hline Chromium & 0.01 & ICP-AES \\
\hline Cobalt & 0.05 & ICP-AES \\
\hline Copper & 0.02 & ICP-AES \\
\hline Dissolved organic carbon & 1.0 & UV promoted oxidation-IR \\
\hline Total cyanide & 0.010 & Colorimetric \\
\hline Fluoride & 0.10 & ISE \\
\hline Iron & 0.03 & ICP-AES \\
\hline Lead & 0.003 & GFAA, ICP-MS \\
\hline Magnesium & 0.10 & ICP-AES \\
\hline Manganese & 0.01 & ICP-AES \\
\hline Mercury & 0.0002 & CVAA \\
\hline Molybdenum & 0.01 & ICP-AES \\
\hline Nickel & 0.04 & ICP-AES \\
\hline Nitrate as $\mathrm{NO}_{3}$ & 1.0 & Colorimetric, IC \\
\hline Potassium & 0.10 & ICP-AES, FAA \\
\hline Selenium & 0.005 & GFAA, $\mathrm{NaBH}_{4}$ \\
\hline Silver & 0.01 & ICP-AES \\
\hline Silica as $\mathrm{SiO}_{2}$ & 0.10 & ICP-AES \\
\hline Sodium & 1.0 & ICP-AES, FAA \\
\hline Strontium & 0.01 & ICP-AES \\
\hline Sulfate & 1.0 & IC \\
\hline Sulfide & 1.0 & $\begin{array}{l}\text { Titrimetric, } \\
\text { colorimetric }\end{array}$ \\
\hline Thallium & 0.005 & GFAA, ICP-MS \\
\hline
\end{tabular}


Table 4.2 UMTRA Project detection limits and techniques (Concluded)

\begin{tabular}{|c|c|c|}
\hline Parameter & $\begin{array}{l}\text { Contract-required } \\
\text { detection limit } \\
\text { (mg/L) }\end{array}$ & Technique(s) $^{\mathrm{a}}$ \\
\hline Tin & 0.05 & $\begin{array}{l}\text { ICP-AES, GFAA, } \\
\text { ICP-MS }\end{array}$ \\
\hline Total dissolved solids & 10 & Gravimetric \\
\hline Total Kjeldahl nitrogen & 1.0 & Colorimetric \\
\hline Total organic carbon & 1.0 & $\begin{array}{l}\text { UV promoted } \\
\text { oxidation-IR }\end{array}$ \\
\hline Total phosphorus as $\mathrm{PO}_{4}$ & 0.10 & Colorimetric \\
\hline Uranium & 0.001 & ICP-MS, fluorometric \\
\hline Vanadium & 0.01 & ICP-AES \\
\hline Zinc & 0.05 & ICP-AES \\
\hline Parameter & $\begin{array}{l}\text { Lower limit } \\
\text { of detection } \\
\text { (pCi/L) }\end{array}$ & Technique(s) $^{\mathrm{a}}$ \\
\hline Gross alpha & 1.0 & PC \\
\hline Gross beta & 0.5 & PC \\
\hline $\mathrm{Pb}-210$ & 1.5 & LSc, PC \\
\hline Po-210 & 1.0 & $A S, P C$ \\
\hline Ra-226 & 1.0 & AS, ASc \\
\hline Ra-228 & 1.0 & PC \\
\hline Th-230 & 1.0 & AS \\
\hline
\end{tabular}

a Where more than one technique is specified, the first technique listed is preferred. Technique acronyms and abbreviations are defined below.

$\begin{array}{ll}\text { AS } & \text { Alpha spectrometry } \\ \text { ASc } & \text { Alpha scintillation } \\ \text { CVAA } & \text { Cold vapor atomic absorption spectroscopy } \\ \text { FAA } & \text { Flame atomic absorption spectroscopy } \\ \text { GFAA } & \text { Graphite fumace atomic absorption spectroscopy } \\ \text { IC } & \text { lon chromatography } \\ \text { ICP-AES } & \text { Inductively coupled plasma-atomic emission spectroscopy } \\ \text { ICP-MS } & \text { Inductively coupled plasma-mass spectrometry } \\ \text { IR } & \text { Infrared } \\ \text { ISE } & \text { lon specific electrode } \\ \text { LSC } & \text { Liquid scintillation } \\ \text { NaBH } & \text { Sodium borohydride reduction atomic absorption spectroscopy } \\ \text { PC } & \text { Proportional counter } \\ \text { UV } & \text { Ultraviolet }\end{array}$




\subsection{SAMPLE COLLECTION METHODS AND SEQUENCE}

Water samples and other environmental samples will be collected according to the following SOPs (JEG, n.d.):

14.5.1 Procedures for Handling and Shipping of Geotechnical Samples

16.1.6 Soil-Water Sampler Installation and Sample Collection

16.1.10 Field Measurements for Temperature, Conductivity, $\mathrm{pH}$, Alkalinity, and Total Acid

16.1.11 Sample Collection for Organic Substances

16.1.13 Field Determination of Oxidation/Reduction Potential in Water Samples

16.1.14 Field Determination of Dissolved Oxygen in Water Samples

16.1.16 Alternate Method For Determination of Dissolved Oxygen

16.1.21 Measurement of Water Turbidity

16.2.1 Sample Collection, Preservation, and Shipment of Water Samples

16.2.2 Water Sampling for Tritium Analysis

16.2.4 Sampling Radon in Water

16.2.5 Monitor Well Sampling With an Electric Submersible Pump

16.2.6 Monitor Well Sampling With a Bladder Pump

16.2.7 Monitor Well Sampling With a Peristaltic Pump

16.2.8 Quality Control Samples for Water Sampling

16.2.9 Monitor Well Sampling With a Bailer

16.3.1 Inventory and Documentation of Damage and Repair of UMTRA Project Wells 


\subsection{SAMPLING PLAN}

\subsection{SAMPLING LOCATIONS}

\section{Ground water locations}

Alluvial monitoring wells NAT-01-0505, $-0506,-0546,-0547$, and -0548 (Figure 1.3) will be sampled to assess baseline conditions at the processing site, and to assess a possible natural flushing compliance strategy. Private wells NAT-01-0907 and -0908 (Figure 1.4) will be sampled to verify the assessment of background ground water quality.

No sampling is planned for wells at the site completed in the Salt Wash Member of the Morrison Formation because the vertical gradient from the Salt Wash Member to the alluvial aquifer is $0.04 \mathrm{ft} / \mathrm{ft}(.01 \mathrm{~m} / \mathrm{m})$ in the upward direction (based on information from NAT01-0502 and -0503); and nine years of sampling at the site (including the Salt Wash Member locations) has not indicated any trends with respect to site related contamination.

No sampling is planned at either the Dry Flats or Coke Oven Valley sites, because Dry Flats is no longer considered as a potential disposal site and sufficient data has been collected from both locations to resolve any outstanding issues.

\section{Surface water locations}

Surface water sample locations are as follows: NAT-01-0531, $-0532,-0533,-0538$, $-0539,-0540,-0556$, and -0557 (Figure 1.4). Samples NAT-01-0531 through -0533 are routine surface sampling locations that are monitored to assess preconstruction conditions. New sample location NAT-01-0556 is on the San Miguel River in an area identified in the risk assessment as a likely discharge area for the alluvial aquifer underlying the site. Locations NAT-01-0538, -0539 , and -0540 are spring/pond features located in the San Miguel River floodplain and are being sampled to provide characterization data for contaminated ground water discharging to the surface downgradient or upgradient (NAT-01-0540) of the site. An attempt will be made to locate a background sampling point to spring NAT01-0538. This new location will be numbered NAT-01-0557.

\subsection{ANALYTICAL PARAMETERS}

Both filtered and unfiltered samples will be collected and the following parameters will be measured at each location in the field: $\mathrm{pH}$, alkalinity, specific conductivity, temperature, dissolved oxygen, and oxidation/reduction potential. The analytical parameters should be evaluated after each sampling event. 
Analytical parameters for ground water and surface water at the processing site are:

\begin{tabular}{|c|c|c|c|}
\hline $\begin{array}{l}\text { Silver" } \\
\text { Molybdenum* } \\
\text { Uranium* } \\
\text { Potassium } \\
\text { Sulfate } \\
\text { Lead-210* } \\
\text { Nitrate }\end{array}$ & $\begin{array}{l}\text { Aluminum* } \\
\text { Antimony } \\
\text { Calcium } \\
\text { Magnesium } \\
\text { Strontium } \\
\text { Polonium-210* }\end{array}$ & $\begin{array}{l}\text { Arsenic } \\
\text { Selenium } \\
\text { Chloride } \\
\text { Sodium } \\
\text { Radium-226* } \\
\text { Iron* }\end{array}$ & $\begin{array}{l}\text { Manganese* } \\
\text { Vanadium* } \\
\text { Fluoride } \\
\text { Silica } \\
\text { Radium-228* } \\
\text { Ammonium }\end{array}$ \\
\hline
\end{tabular}

- Parameters analyzed for in unfiltered samples.

\subsection{SAMPLING FREQUENCY}

The range of linear flow velocities in the alluvial aquifer at the Naturita site is likely from 20 to $200 \mathrm{ft}$ (6 to $61 \mathrm{~m}$ ) per year but could possibly be as high as $2000 \mathrm{ft}$ $(610 \mathrm{~m})$ per year (DOE, 1994b, Calculation number NAT-08-89-14-07-00; DOE, 1995b). Based on this information, and to comply with recommendations of the BLRA (DOE, 1995b), monitoring will continue on a semiannual basis for the next two years (fiscal years 1996 and 1997). Following this sampling, the ground water trends and sampling frequency should be reevaluated. The risk assessment recommended building a statistically defensible data set for ground water decisions and collecting site-specific information on the seasonal aspects of surface water/ground water interaction to verify assumed recharge and discharge characteristics of the alluvial aquifer. Natural flushing could potentially be used as a ground water compliance strategy for the Naturita site, and semiannual sampling may serve to document natural flushing at the site. In addition, ground water should be monitored for trends in constituent concentrations during surface remediation (scheduled to be complete during 1998).

\subsection{DATA EVALUATION METHODS}

Data results will be compared to previous historical data and to background to determine changes or trends in site-related contaminants. Decreases or increases in constituent concentrations will be evaluated to determine:

- If there is evidence for increased or decreased levels of contamination in ground water or surface water which would effect the conclusions of the BLRA (DOE, 1995b).

- If there is evidence that maximum concentration limits (MCL) were exceeded for the first time at the sampled location.

- If there is evidence of movement of contaminated ground water into areas not previously identified as being contaminated.

- If there is evidence of a change in the San Miguel River quality that may affect the quality and health of human and nonhuman life. 


\subsection{RESPONSE TO ANOMALOUS DATA}

Anomalous data will be handled according to AOM SOPs 16.3.2, "Validation of chemical Analysis Data," and 16.3.3, "Data Management" (JEG, n.d.). Data will be compared the range of expected values for each ground water and surface water sampling location (if known). This list includes both physical parameters, such as ground water levels, and chemical parameters, such as $\mathrm{pH}$ and uranium. Future data that lie outside of these ranges will be assessed to determine if the value is reasonably expected given the standard deviation of previous sampling rounds, or the existence of trends. If the value is not reasonably expected, then field and laboratory records will be checked for the possibility of a sampling or transcription error. If that is not the case, remaining sample (if any) will be reanalyzed to determine if the value is an analytical error. If the anomalous data cannot be shown to be due to sampling or analytical errors, then the well will be resampled for the anomalous parameter during the next sampling event. 


\subsection{LIST OF CONTRIBUTORS}

The following individuals contributed to the preparation of this document.

\begin{tabular}{ll}
\hline Name & Contribution \\
\hline C. Yancey & Document coordinator \\
K. Smith & Statistics \\
J. Carman & Hydrogeology \\
D. Erskine & Geochemistry \\
A. Holm & Senior technical review \\
E. Arliglia & Site manager \\
& Graphic designer \\
WordCenter, Inc. & Text processing \\
D. Tamez & Technical editor \\
\hline
\end{tabular}


UNTRA PROJECT WATER SANPLING AND ANALYSIS PLAN, NATURITA, COLORADO 


\subsection{REFERENCES}

Ackerman, D.J., and F. E. Rush, 1984. Hydrogeological Reconnaissance of the San Miguel River Basin, Southwestem Colorado, U.S. Geological Survey, Water Resources Investigation Report 84-4133, USGS, Lakewood, Colorado.

Brod, R. C. and Stone, W. J., 1981. Hydrogeology of Ambrosia Lake - San Mateo area, McKinley and Cibola Counties, New Mexico: Hydrologic Sheet 2 New Mexico Bureau of Mines and Mineral Resources, Socorro, New Mexico.

DOE (U. S. Department of Energy), 1995a Supplement to the Baseline Risk Assessment Ground Water Contamination at the Uranium Mill Tailings Site Near Naturita, Colorado, UMTRA-DOE/AL-62350-195S, prepared by the U.S. Department of Energy, Environmental Restoration Division, UMTRA Project Team, Albuquerque, New Mexico.

DOE (U. S. Department of Energy), 1995b. Baseline Risk Assessment of Ground Water Contamination at the Uranium Mill Site Near Naturita, Colorado, UMTRA-DOEIAL62350-195, Rev. 0, U.S. Department of Energy, Environmental Restoration Division, UMTRA Project Team, Albuquerque, New Mexico.

DOE (U. S. Department of Energy), 1994a. Environmental Assessment of Remedial Action at the Naturita Uranium Processing Site Near Naturita, Colorado, DOE/EA-0464, U.S. Department of Energy, UMTRA Project Office, Albuquerque Operations Office, Albuquerque, New Mexico.

DOE (U. S. Department of Energy), 1994b. Remedial Action Plan for the Inactive Uranium Processing Site at Naturita, Colorado, UMTRA-DOE/AL/62350-142, Rev. 0, U.S. Department of Energy, UMTRA Project Office, Albuquerque Operations Office, Albuquerque, New Mexico.

DOE (U. S. Department of Energy), 1989. Technical Approach Document, UMTRA-DOE/AL050425.0002, U.S. Department of Energy, UMTRA Project Office, Albuquerque Operations Office, Albuquerque, New Mexico.

Evans, A. M., 1987I. An Introduction to Ore Geology, Blackwell Scientific Publications, Boston, Massachusetts, $358 \mathrm{p}$.

FBDU (Ford, Bacon \& Davis Utah, Inc.), 1981. Engineering Assessment of Inactive Uranium Mill Tailings, Naturita Site, Naturita, Colorado, DOE/UMT-012, FBDU 360-08, UC-70, prepared by FBDU, Salt Lake City, Utah, for the U.S. Department of Energy, UMTRA Project Office, Albuquerque Operations Office, Albuquerque, New Mexico.

Fenneman, N. M., 1946. Physical Divisions of the United States: U.S. Geological Survey map, scale 1:7,000,000 (Reprinted, 1964). 
JEG (Jacobs Engineering Group Inc.), n.d. Albuquerque Operations Manual, standard operating procedures, prepared by Jacobs Engineering Group, Albuquerque, New Mexico, for the U.S. Department of Energy, UMTRA Project Office, Albuquerque Operations Office, Albuquerque, New Mexico.

Merritt, R. C., 1971. The Extractive Metallurgy of Uranium, Colorado School of Mines Research Institute, Golden, Colorado.

USGS (U.S. Geological Survey), 1979. Water Resources Data for Colorado, Water Year 1978, Vol. 3, Dolores River Basin \& Green River Basin, Denver, Colorado.

Weir et al. (J. E. Weir, Jr., E. Blair Maxfield, and E. A. Zimmerman), 1984. Regional Hydrology of the Dolores River Basin, Eastem Paradox Basin, Colorado and Utah, WaterResources Investigation Report 83-4217, U.S. Geological Survey.

\section{CODE OF FEDERAL REGULATIONS}

40 CFR Part 192, Health and Environmental Protection Standards for Uranium and Thorium Mill Tailings, U. S. Environmental Protection Agency. 